\title{
Nordic Journal of Political Economy
}

\begin{tabular}{lll} 
Volume 32 & $2006 \quad$ Pages 17-50 \\
\hline
\end{tabular}

\section{Equity, Institutions and the Development Process}

James A. Robinson

This article can be dowloaded from:

http://www.nopecjournal.org/NOPEC 2006 a02.pdf

Other articles from the Nordic Journal of Political Economy can be found at: http://www.nopecjournal.org 


\author{
James A. Robinson*
}

\title{
Equity, Institutions and the Development Process
}

\begin{abstract}
In this essay I argue that to develop institutions that promote economic development societies must be equitable in fundamental ways. I particularly emphasize how important an equitable distribution of political power in society is to have well functioning institutions that support market activities. I show these ideas are consistent with broad patterns in the cross-national data and country case studies.
\end{abstract}

Investment in physical and human capital, or in new technologies and ways of doing things, is the basic activity that makes a country prosperous. When markets are imperfect many socially desirable investment opportunities will be passed up. Moreover, the extent to which they are passed up can depend on the distribution of resources and hence the extent of equity. A more equitable society may be more efficient because it allows the relatively poor to invest (see for example Banerjee and Newman, 1993).

However, equitable societies don't just do better for a given set of institutions, they also tend to have better institutions. To make this argument I need to broaden the set of institutions under consideration beyond the types of market institutions which are the usual focus of economists. Obviously the nature of product, land, labor and capital markets are crucial for the allocation of resources and development. But market institutions exist and function in the context of a whole set of non-market and political institutions. I argue here that the nature of these other institutions and the way they function are influenced by how equitable society is.

The most obvious institutions complementary to market activities are the definition

* Harvard University, Department of Government, CIAR, CEPR and NBER, 1737 Cambridge Street, N309, Cambridge MA02138, USA.

I am greatly indebted to Abhijit Banerjee, François Bourguignon, Francisco Ferreira, Elizabeth Perry, Michael Walton and Michael Woolcock for their suggestions and advice. 
and enforcement of property rights and contracts. People will not invest if property rights are not well defined and enforced, or if they believe that the contracts that they write will not be honored or that courts of law will be subverted. Market institutions must also be complemented by a whole set of other inputs that the state must provide apart from social order and fair contract enforcement. These include various types of public goods and infrastructure and regulations. Thus lying behind well functioning markets are legal systems, judges, policemen and ultimately social groups and politicians.

Such institutions, since they determine the incentives and constraints people face and the types of activities that they undertake necessarily help to determine the distribution of resources. Different sets of institutions are the outcome of complex historical processes, but they also reflect the interests of individuals and groups in society and thus the structure of political influence and power. Those with the power to determine or mould the structure of institutions may therefore do so with an eye to how they influence their own welfare rather than that of society. From this perspective, particular sets of institutions may arise because they distribute income or perhaps power itself in particular ways. We cannot guarantee therefore that societies will end up with the institutions best designed to promote prosperity since institutions that do not generate development may nevertheless be highly advantageous to some politically influential group in society.

In this essay I shall consider the processes of the creation of institutions and the circumstances in which institutions that are complementary to market activity and hence promote prosperity arise. I shall argue that, in essence, societies which successfully manage to create sets of institutions that generate sustained prosperity are equitable in impor- tant ways. That this is so can be seen by dwelling on how good non-market institutions must function. Since talent and ideas are widely distributed in the population, it is crucial that the property of all people is secure and that there is equality before the law for all and not just for some. This also implies that a good institutional environment will not block entry into new lines of business and that the political system will provide access and public goods to all. Thus good non-market institutions must be equitable.

These definitions suggest institutions were not good in slave societies, such as Haiti or Barbados in the 18th century. Even though property rights in land and people were well defined and even well enforced (though subject to potential slave rebellions) most people had no property rights at all and were thus subject to expropriation by others, particularly their masters. Thus $95 \%$ of the society had no incentives to engage in socially desirable activities. A similar, though somewhat less extreme example of bad institutions is South Africa under apartheid. There, institutions were good for the whites, but this left $80 \%$ of the population without incentives and with few opportunities.

How do societies develop good equitable non-market institutions? I argue that this requires that there must be sufficient political equality. By political equality I mean equality in the distribution of political power, of political rights, influence, and of access to the political system. At root it is the fact that one has relative political influence that secures one's property, or gives one access to the law on the same terms as others. It is this that provides equality of opportunity. Political equality will be important because it helps to determine the types of institutions that are chosen, or perhaps what inherited institutions persist and what change.

Poor institutions will emerge and persist 
in societies when power is relatively concentrated in the hands of some narrow group or elite. Such an elite may grant property rights to itself, but the property rights of most citizens will be unstable. There may be equality before the law for this elite, but not for the majority of people. Government policies may favor such an elite, granting them rents and monopolies, but most people will be excluded from entering profitable lines of business. The educational system may invest heavily in the children of such elites, but most will be excluded.

The distribution of political power in society will be determined by many things, for instance formal political institutions such as the constitution and the nature of checks and balances and the ability of different groups to solve the collective action problem. But underpinning political inequality is often economic inequality. In a society where inequalities of assets and incomes are larger the rich will tend to have relatively more influence and will have a comparative advantage in adapting and distorting institutions to their benefit.

Since political equality, through its impact on institutions, clearly helps to determine the distribution of income, we see the clear possibility of vicious and virtuous circles. A society with greater equality of assets and incomes will tend to have more equal distributions of political power. It will therefore tend to have better institutions which generate equality of opportunity for the broad mass of citizens. This will tend to spread rewards and incomes widely reinforcing the initial distribution of incomes. A society with greater inequality of assets and incomes will tend to have a relatively inegalitarian distribution of power and worse institutions. This tends to reproduce the initial conditions. In this essay I use historical and case study evidence to argue that the first type of society will tend to be more prosperous. I shall argue that societies which are today prosperous are so because they developed more egalitarian distributions of political power, while poor societies often suffer from inbalanced distributions. I shall also suggest some ideas about how societies made the transition from one equilibria to the other.

When institutions have distributional effects there is naturally conflict over institutions. One set of institutions will benefit some people, while another will benefit different people. There will therefore be incentives for people to control power in order to create or keep the institutions that benefit them and avoid the institutions that disadvantage them. How intense this conflict is depends on who is in conflict with whom. For example, if the groups in conflict are defined along ascriptive lines, such as ethnicity, then this may induce a more severe form of conflict than when groups are defined on other lines, or when there are cross-cutting cleavages. More polarized conflict seems to be an independent force leading to bad institutions and we shall see below how these ideas can help to explain the relative economic success of Mauritius.

Political equality also matters for the quality of public policy. The basic role of the state is to provide public goods which private individuals do not have correct incentives to provide themselves. But politicians only have the correct incentives to provide public goods when they have to appeal to the broad mass of citizens to attain power. If they can win power with a small number of key supporters, or with few votes, then they will tend to be 'clientelistic' and be more inclined to buy votes or make individual exchanges of patronage for support without providing the goods and services critical to raising the mass of people out of poverty. 


\section{Figure 1.}

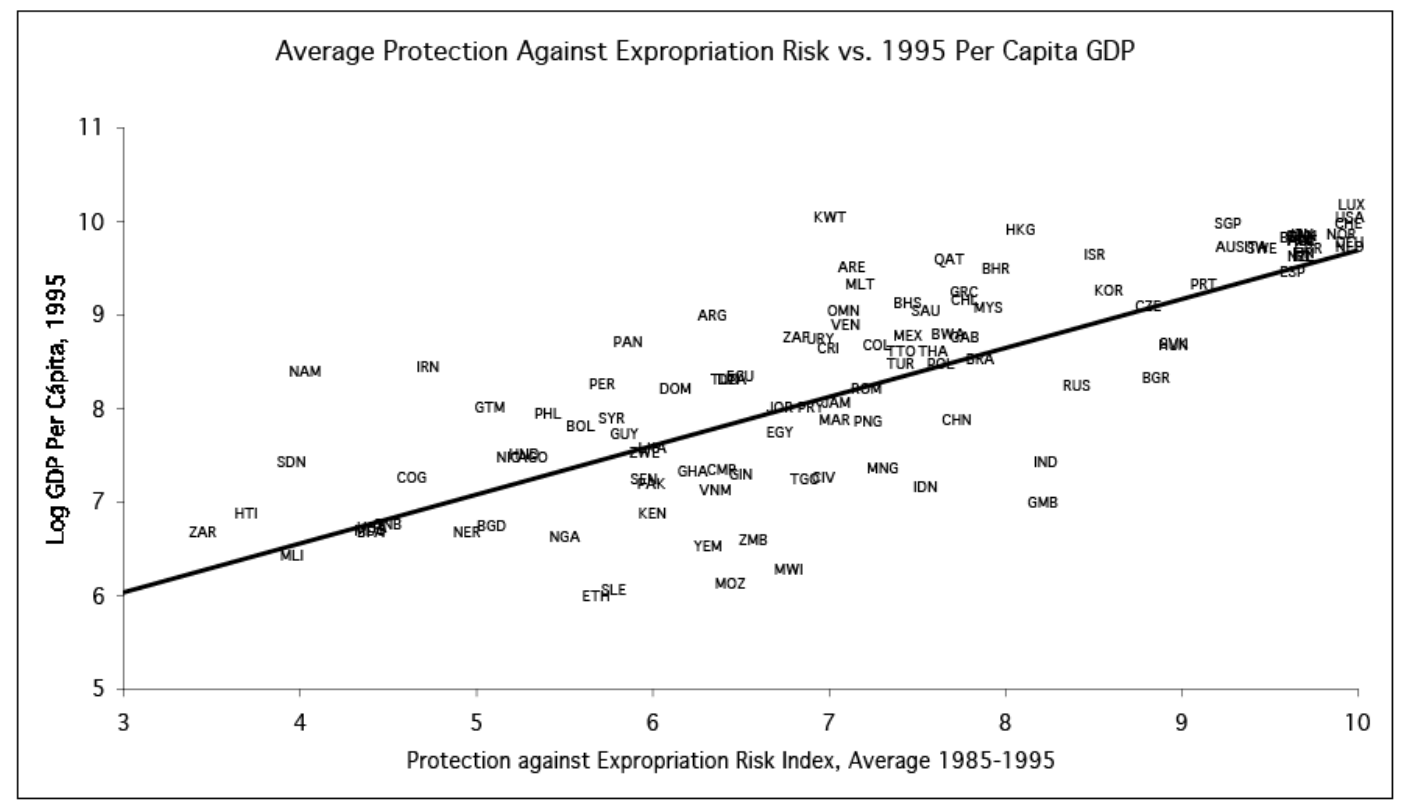

That more egalitarian distributions of political power and income are associated with sustained and enduring prosperity can be seen from some simple patterns in the data. Figure 1 shows the relationship between GDP percapita in 1995 and a measure of the security of property rights, "protection against expropriation risk", averaged over the period 1985 to 1995 . This data on institutions come from Political Risk Services, a private company which assesses the risk that investments will be expropriated in different countries. These data, first used by Knack and Keefer (1995) and subsequently by Hall and Jones (1999) and Acemoglu, Johnson and Robinson (2001, 2002, 2006) are imperfect as a measure of the relevant institutions because they pertain to investments by foreigners. Nevertheless, in practice they seem to capture how stable property rights are in general not just for some sub-set of society, and the findings below are robust to using other available measures of related institutions. The scatter plot shows that countries with more secure property rights, i.e., one important aspect of better institutions, have higher average incomes.

The argument of this essay is that better institutions should be associated with greater political equity. Though there is no perfect way of measuring political equality, protection against expropriation risk is highly correlated with both measures of democracy and also measures of 'constraints on the executive' from the Polity IV database. This latter variable is designed to capture the extent to which those who control political power are constrained or checked by others. For example, the types of checks and balances and separation of powers written into the US Constitutions would be a classic example of such constraints.

Are political equality and good institutions correlated with greater equality of incomes? The answer is yes, for instance there is a 
negative correlation between constraints on the executive and the Gini coefficient. A higher value of the Gini coefficient corresponds to greater inequality. Countries which are more unequal and consequently have higher Gini coefficients, tend to have fewer constraints on the executive.

The simple correlations and are no doubt consistent with many different causal stories. Nevertheless, I believe that they show that there are complementarities between achieving a relatively egalitarian distribution of political power, good institutions, prosperity, and a relatively egalitarian distribution of economic resources. Despite the tentative nature of this evidence, recent research suggests that one can tell a causal story about this data along exactly the lines we are suggesting.

I outline such a causal story in the next section where I examine historical evidence about the connection between economic and political equality, institutions and development. Section III then examines some contemporary development experiences of growth and stagnation and relates them to the themes of the distribution of political power, resources and institutions. Section IV then focuses on transitions and the issue of how societies can move from vicious circles to virtuous circles. Section V concludes. Before moving to the body of the paper I being with a prelude, taken from the research of Steven Haber, which illustrates many of the important themes.

\section{Banking in 19th century Mexico and the US} Much recent work on growth and development has focused on financial and capital markets. If the stress on financial markets and financial intermediation is correct, a central issue is to understand why financial systems differ. For example, studies of the development of banking in the United States in the nineteenth century demonstrate a rapid expansion of financial intermediation which most scholars see as a crucial facilitator of the rapid growth and industrialization that the economy experienced. In his recent study Haber (2001) investigated the development of banks in $19^{\text {th }}$ century Mexico and the United States. He shows that (p. 24) "Mexico had a series of segmented monopolies that were awarded to a group of insiders." In 1910 "the United States had roughly 25,000 banks and a highly competitive market structure; Mexico had 42 banks, two of which controlled 60 percent of total banking assets, and virtually none of which actually competed with another bank."

The explanation for this huge difference is not obvious. The relevant technology was certainly readily available everywhere and it is difficult to see why the various types of moral hazards or adverse selection issues connected with financial intermediation should have limited the expansion of banks in Mexico, but not the United States. Haber then shows that (p. 9) at the time that the U.S. Constitution was put into effect in 1789 the structure of US banking looked remarkably like that which arose subsequently in Mexico. State governments had been stripped of revenues by the Constitution and in response, states started banks as a way to generate tax revenues and restricted entry to generate rents. Yet this system did not last because states began competing among themselves for investment and migrants (p. 10).

"The pressure to hold population and business in the state was reinforced by a second, related, factor: the broadening of the suffrage. By the 1840 s, most states had dropped all property and literacy requirements, and by 1850 virtually all states ... had done so. The broadening of the suffrage, however, served to undermine the political coalitions that supported restrictions on the number of bank 
charters. That is, it created a second source of political competition-competition within states over who would hold office and the policies they would enact."

The situation was very different in Mexico. After 50 years of endemic political instability the country unified under the highly centralized 40 year dictatorship of Porfirio Diaz until the Revolution in 1910.

In Haber's argument political institutions in the United States allocated political power to people who wanted access to credit and loans. As a result they forced state governments to allow free competitive entry into banking. In Mexico political institutions were very different. There were no competing federal states and the suffrage was highly restrictive. As a result the central government granted monopoly rights to banks who restricted credit to maximize profits. The granting of monopolies turned out to be a rational way for the government to raise revenue and redistribute rents to political supporters (see North, 1981, Chapter 3).

A priori, it is possible that the sort of market regulation Haber found in Mexico might have been socially desirable. Markets never operate in a vacuum, but rather within sets of rules and regulations which help them to function. Yet it is hard to believe that this argument applies to Mexico (see also Maurer, 2002). Haber (2001) documents that market regulation was not aimed at solving market failures and it is precisely during this period that the huge economic gap between the United States and Mexico opened up (on which see Coatsworth, 1993, Engerman and Sokoloff, 1997). Indeed, Haber and Maurer (2004) examined in detail how the structure of banking influenced the Mexican textile industry between 1880 and 1913. They showed that only firms with personal contacts with banks were able to get loans and that such firms were relatively less efficient. Despite the fact that economic efficiency was hurt by regulations, those with the political power were able to sustain them.

\section{Historical Evidence}

In this section I present empirical and historical evidence which is consistent with the claims I made in the introduction. I first discuss how the research of Acemoglu, Johnson and Robinson $(2001,2002)$ allows us to interpret the Figure 1 causally. I then develop these ideas in more detail by turning to the history of comparative development in the Americas.

\section{European Colonization as a Natural Experi- ment in Institutions}

Figure 1 shows the relationship between security of property and prosperity for the whole world. To interpret this causally we need to find an exogenous source of variation in institutions that applies to the whole world. This is a difficult issue, but Acemoglu, Johnson and Robinson (2001) were able to provide a partial answer. They showed that the same basic pattern in Figure 1 holds in a smaller sample of countries, those colonized by Europeans after 1492. The colonization of much of the world by Europeans provides something approximating a large scale 'natural experiment'. Beginning in the early fifteenth century and massively intensifying after 1492 , Europeans conquered many other nations. The colonization experience transformed the institutions in many diverse lands conquered or controlled by Europeans. Most importantly, Europeans created very different sets of institutions in different parts of their global empire, as exemplified most sharply by the contrast between the institutions in the northeast of America and those in the plantation societies of the Caribbean. This 
Figure 2.

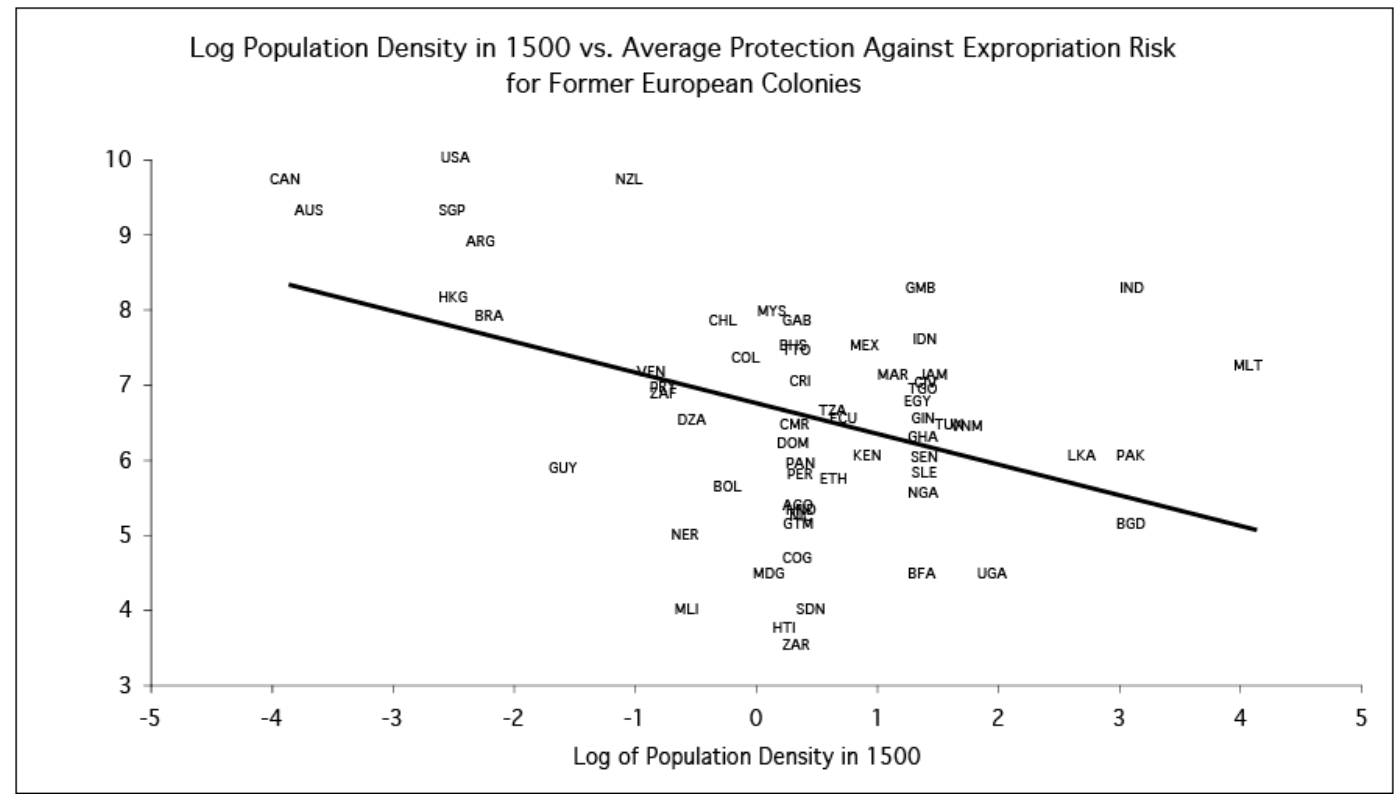

experience provides evidence which persuasively establishes the central role of institutions in development. I shall argue that it also provides relatively clean cut evidence which supports our conjectures about the joint evolution of prosperity and political and economic equality.

\section{Institutional Origins}

The explanation proposed by Acemoglu, Johnson and Robinson for why Figure 1 holds for former colonies, is that Europeans created good institutions in some colonies, particularly places such as the United States, Canada and Australasia (what Crosby, 1986, calls the 'neo-Europes'), and bad ones in others (for example Latin America or Sub-Saharan Africa). These institutions had a strong tendency to persist over time and thus generate Figure 1 today. Why did different institutions develop in different European colonies? The simplest answer is that the institutions in various colonies were shaped by Europeans to benefit themselves. Moreover, because conditions and endowments differed between colonies, Europeans consciously created different institutions. There are several important empirical regularities connecting these initial conditions to current outcomes. Of particular importance are initial population density, the disease environment faced by Europeans and the nature of factor endowments that influenced economic organization (Engerman and Sokoloff, 1997). Figure 2 shows that there is a strong inverse relationship between population density in 1500 and current expropriation risk for former European colonies.

Figure 3 shows that colonies where the disease environment was worse for Europeans also have worse institutions today.

Other aspects of factor endowments are more difficult to measure directly but Engerman and Sokoloff (1997) point out how in places 
Figure 3.

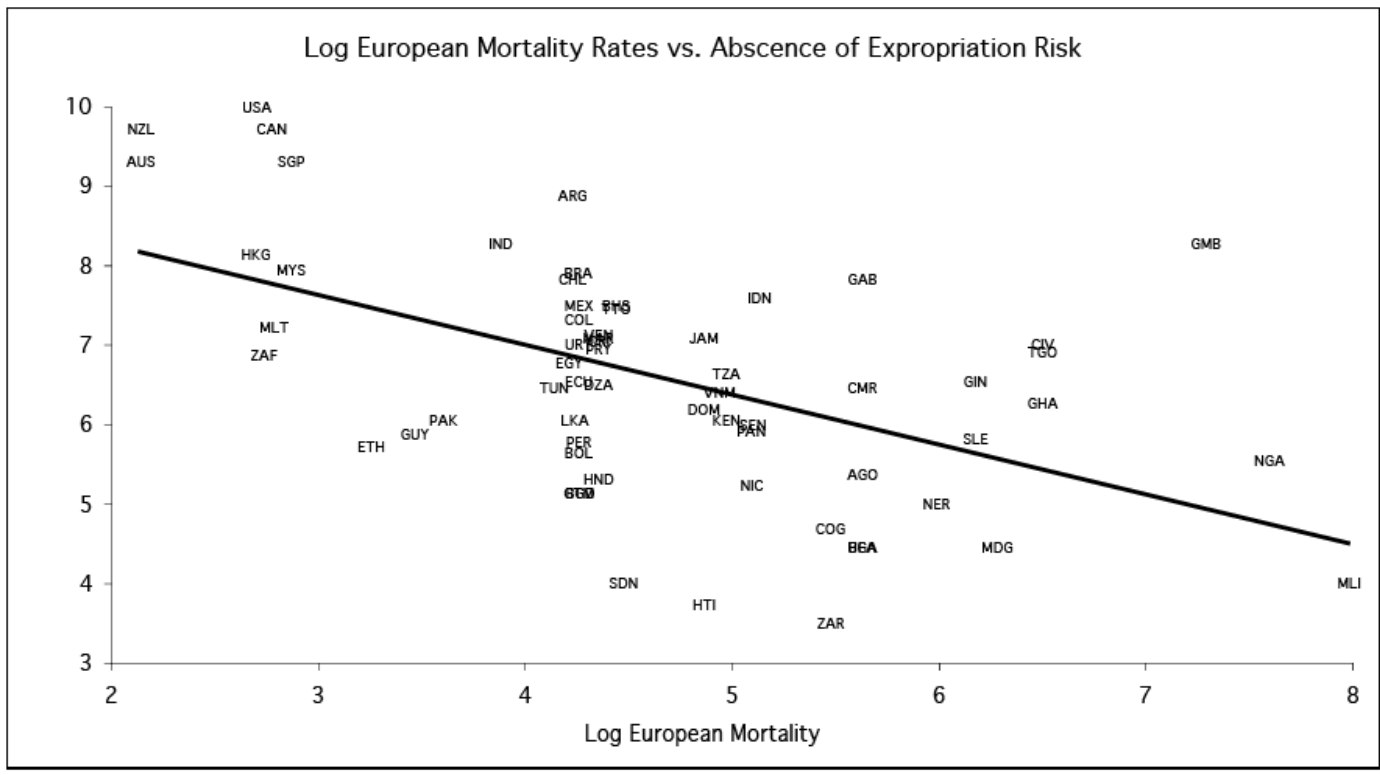

where the climate and soils were suitable for crops such as sugarcane which could be grown on large plantations with slave labor, such as northeastern Brazil, much worse institutions and skewed distributions of political power evolved than in climates where wheat or other non-plantation crops could be grown.

Why did Europeans introduce better institutions in previously relatively unsettled and healthy areas than in previously denselysettled and unhealthy areas? How did factor endowments more generally influence institutions? Europeans were more likely to introduce or maintain bad institutions in places where there were a lot of resources and rents to extract. These resources included gold and silver, but most importantly people. In places with a large indigenous population, Europeans could exploit the population, be it in the form of taxes, tributes or employment as forced labor in mines or plantations. Moreover, in places where plantation crops could be profitably grown, slave based societies emerged. These types of colonization were incompatible with institutions providing economic or civil rights or equality of opportunity to the majority of the population. Consequently, a more developed civilization with a denser population structure, and particular climatic and agricultural conditions, made it more profitable for the Europeans to introduce bad institutions.

In contrast, in places with little to extract, where plantation agriculture was not profitable, and in sparsely-settled places where the Europeans themselves became the majority of the population, it was in their interests to introduce much better institutions.

In addition, the disease environments differed markedly among the colonies, with obvious consequences for the attractiveness of European settlement. When Europeans settled, they established institutions that they themselves had to live under. 
Figure 4 .

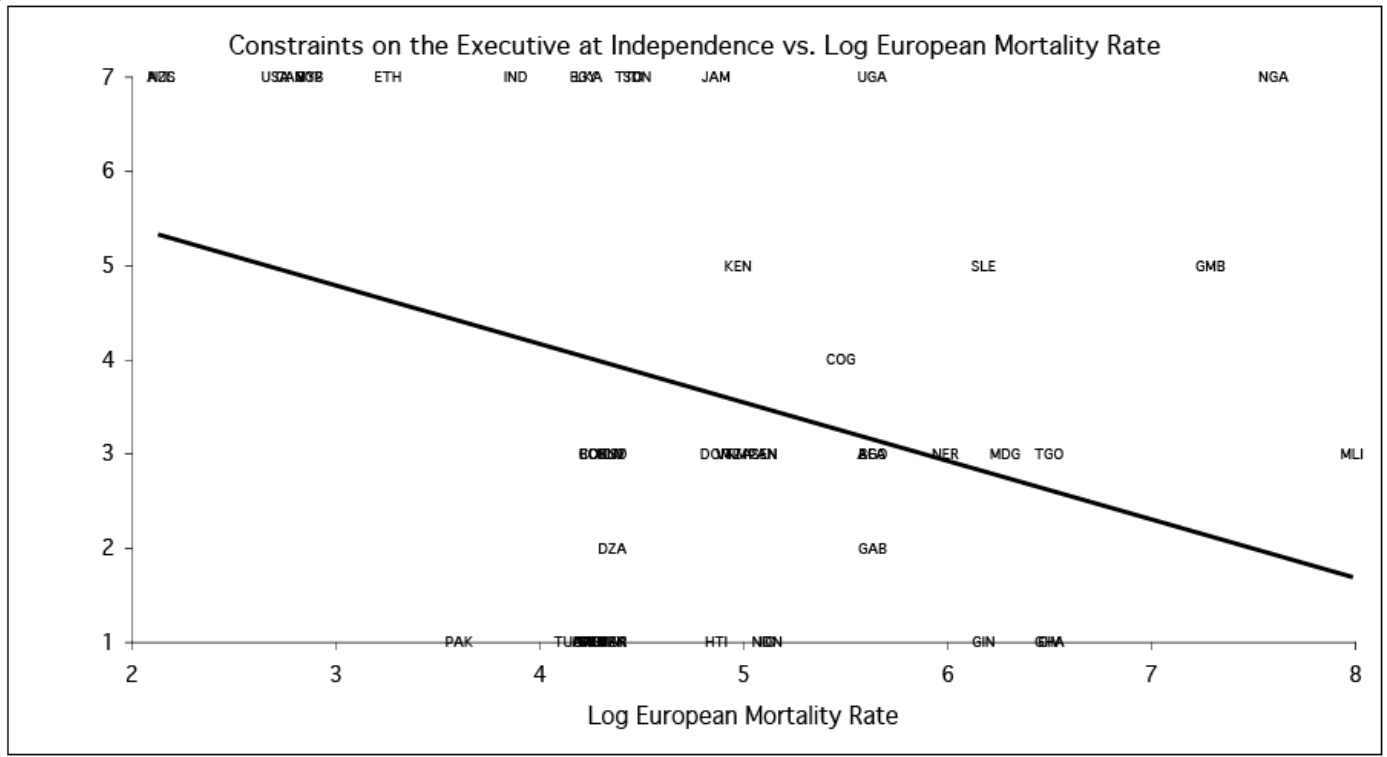

Acemoglu, Johnson and Robinson (2001) developed this argument and investigated it empirically. They used initial conditions in the European colonies on the mortality rates faced by Europeans (primarily soldiers, sailors, and bishops), as instruments for current institutions. ${ }^{1}$ Figure 3 shows the very strong relationship between the historical mortality risk faced by Europeans and the current extent to which property rights are enforced. This research suggests that most of the gap in percapita income between rich and poor countries today is due to differences in institutions. More precisely, they showed (p. 1387) that if one took two typical-in the sense that they both lie on the regression line-countries with high and low expropriation risk, like Nigeria and Chile, then almost the entire difference in income per-capita between them could be explained by the differences in the security of property rights. They also presented regression evidence that showed that once the effect of institutions on GDP per-capita was properly controlled for, geographical variables, such as latitude, whether or not a country is land-locked and the current disease environment, have no explanatory power for current prosperity.

\section{Interpretation}

Different types of societies developed in different colonies with radically different implications for subsequent development.

1. Since the disease environment 200 or more years ago affects outcomes today only through its effect on institutions today, then we can use this historical disease environment as an exogenous source of variation in current institutions. From an econometric point of view we have a valid instrument which will enable us to identify the casual effect of institutions on prosperity. 
Figure 5.

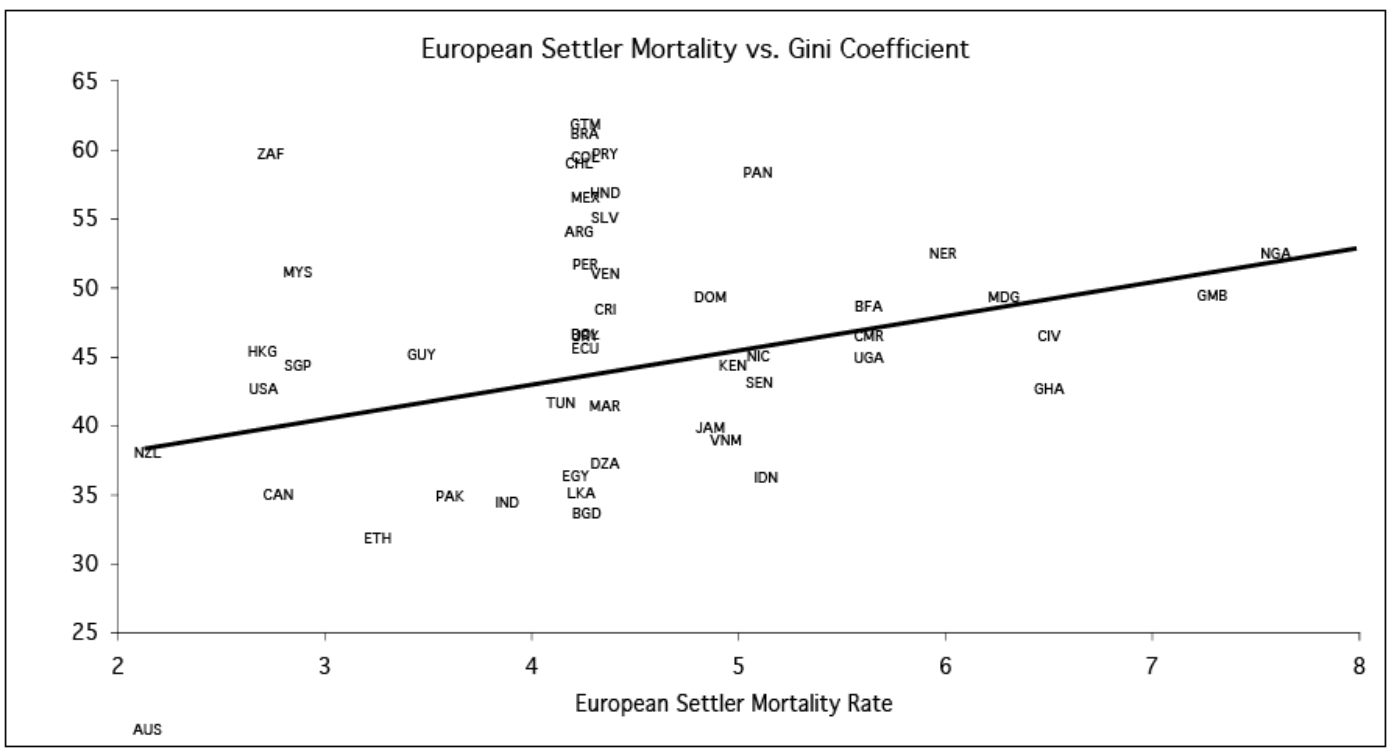

Crucially, the societies that emerged in the Neo-Europes had distributions of economic resources and political power that were much broader. Moreover, constraints were placed on the exercise of political power and the ability of elites to adopt policies favorable to themselves, but deleterious for society. This is shown more systematically in Figure 4 which plots constraints on the executive measured at the year when a country became independent, against settler mortality. It is clear here that the same factors that gave rise to good institutions gave rise to a more egalitarian distribution of power.

As I am arguing, there is a connection between the emergence of these two things. Without political power it is impossible for a person's property rights to be guaranteed, or for them to have real access to the legal system to make sure that contracts are honored. In these societies a more egalitarian distribution of political power is also associated with an egalitarian distribution of economic resources.

I now investigate these connections in a deeper way by considering the historical evolution of the Americas over this period.

Origins of Development and Inequality in the Americas

\section{Latin America}

The colonization of Latin America began with the discovery of the 'Indies' by Columbus in 1492, the assault on Mexico by Cortes after 1519 and the conquest of Peru by Pizzaro after 1532. The Spanish, from the beginning, were interested in the extraction of gold and silver, and then later in taking tribute and raising taxes. The colonial societies which emerged were authoritarian and based on the political power of a small Spanish elite who created a set of institutions designed to extract wealth from the indigenous population.

After Pizzaro conquered Peru he imposed a series of institutions designed to extract rents 
from the newly conquered Indians. The main such institutions were the encomienda (which gave Spanish conquistadors the right to Amerindian labor, Klarén, 2000, pp. 44-48), the mita (a system of forced labor used in the mines), and the repartimiento (the forced sale of goods to Indians, typically at highly inflated prices). Pizzaro created 480 encomenderos (Hemming, 1970, p. 264) under whose 'care' the entire Indian population was placed. In other colonies the situation was similar. For instance in the territory comprising modern Colombia there were about 900 encomenderos (Melo, 1996, p. 222).

The institution of the encomienda did not last for long in all parts of the empire since the Spanish Crown attempted to curtail it by the end of the 16th century, nevertheless the mita (from the Quechua word mit'a meaning 'turn') became a central institution right until independence (Bakewell, 1984, Cole, 1985) and forced labor lasted far beyond this in most of Latin America (for instance until 1945 in Guatemala). The institution of the encomienda also persisted because the concentration of political power with which it was closely associated subsequently led to the emergence of large landed estates (Lockhart, 1969, and Mörner, 1973).

The feasibility and attraction of this type of economic system was determined by the relatively high population densities of indigenous people in many parts of the Spanish empire and also the extent to which such societies had already developed into 'complex societies' (Lockhart and Schwartz, 1983, p. 34).

Other institutions were designed to reinforce this system. For instance the legal system systematically discriminated against indigenous people. Indigenous people were not allowed to give testimony in some sorts of cases and in others the testimony of 10 was equal to that of one Spaniard (Parry, 1948).
Although indigenous people did use the legal system to challenge aspects of colonial rule, they could not alter the main parameters of the system. In addition to all of this the Spanish Crown created a complex web of mercantilistic policies and monopolies from salt to gunpowder, from tobacco to alcohol and playing cards in order to raise revenues for the state.

Spanish colonies that had small populations of Amerindians, such as Costa Rica, Argentina, or Uruguay, seem to have followed different paths of institutional development. The sharp contrasts along many institutional dimensions between Costa Rica, which had relatively few Native Americans, and Guatemala where population density was greater has been much studied (e.g. Cardoso, 1991). Interestingly, although the formal political institutions within the Spanish empire were the same everywhere, there is evidence that the way they functioned depended on the local conditions (Lang, 1975, p. 28).

The set of institutions that emerged in the main Spanish colonies greatly benefited the Spanish crown and the Spanish settler elite, yet they did not promote the prosperity of Latin America. The vast majority of the population had no property rights, no incentives to enter into socially desirable occupations or to invest. These institutions were created by and sustained in the context of a set of political institutions and a particular balance of political power and highly unequal distributions of assets and income. In South America, Europeans developed coercive regimes monopolizing military and political power, and respecting few constraints on this power (unless they were imposed by the mother country in Europe). These political institutions generated the structure and incentives that ensured their own continuation, and the continuation of a set of 
institutions which did not provide good incentives for the great mass of society.

\section{North America}

The history of North America is in stark contrast. Initial attempts at colonization were also based on economic motivations. British America colonies were founded by entities such as the Virginia Company and the Providence Island Company whose aim was to make profits. The model that they had in mind was not so different from that adopted by the Spanish or Portuguese (a system that other British colonizing entities, such as the East India Company, used to great effect). Yet these colonies did not make money and indeed both the Virginia Company (Craven, 1932) and the Providence Island Company (Kupperman, 1993) went bankrupt. A colonial model involving the exploitation of indigenous labor and tribute systems was simply infeasible in these places, because of lack of a large indigenous population and the absence of complex societies.

For example, large land grants were made by Charles I to encourage settlers to move to America, and in 1632 Maryland was given to the second Lord Baltimore (about 10 million acres). The charter also gave Baltimore "virtually complete legal authority over his territory, with the power to establish a government in whatever form he wished" (Galenson, 1996, p. 143). His idea was to attract tenants from Britain and set up a huge manorial system. This approach to colonization was not so different to the one employed by the Portuguese in Brazil. And yet, things were different in North America and, "the manorial organization of Baltimore's colony failed to materialize, as Maryland's history during the 17th century witnesses the gradual breaking down of rigid proprietary control" (Galenson, 1996, p. 143). The situation in Pennsylvania, granted by Charles II to William Penn in 1681 was similar.

In these colonies institutions ended up providing access to land to a broad crosssection of society, the legal system became relatively impartial, ensuring secure property rights for smallholders and potential investors. These institutions created not only good incentives for investment, but also made such investment possible by generating financial development and an environment for secure contracting and business relationships. Lying behind these institutions were relatively representative political institutions and a relatively egalitarian distribution of resources. As was the case in the Latin America, there was a synergy between economic and political institutions, but this time it was not a vicious, but a virtuous one; institutions giving and protecting property rights for the great mass of people and relatively democratic political institutions complemented each other, and ensured the continuation of an environment conducive for investment and economic progress.

The emergence of representative political institutions in Virginia was a direct result of a realization by the authorities that the type of colonization strategy that had worked in Peru, would not work in the US because of the different initial conditions. Unlike Peru, in Virginia there was no large centralized tributary empire, but many competing and fragmented tribes. There was no gold or silver and the Indians, not used to paying tribute or engaging in forced labor, would not work. In consequence the settlers of Jamestown starved (see Craven, 1932, Morgan, 1975). In response to these early failures, the Virginia Company tried various incentive schemes, including a highly punitive, almost penal, regime in an effort to make money. Such efforts at labor repression quickly collapsed, however, and by 1619 the Company had 
created an unusually representative set of institutions for that era: a General Assembly with adult male suffrage.

The early history of the United States therefore shows a possible path to the emergence of good institutions; the early attempts to create an oligarchic society with close control of labor quickly collapsed. What emerged instead was a relatively egalitarian society, with representative institutions and where the poorest colonists had access to the law and to some political representation.

The low population density in the United States had a crucial impact on early institutions. Galenson, (1996, p. 143) notes,

"The extreme labor shortage ... allowed many early settlers to gain their economic independence from the manorial lords, and establish separate farms ... Thus just as in Virginia, in Maryland the colonial labor problem undermined the initial plans for a rigid social hierarchy, as Lord Baltimore's blueprints for a manorial society were largely swept away and early Maryland became an open and fluid society, which offered considerable economic and social opportunity."

The situation of Maryland, itself reflecting conditions that had made themselves felt in Jamestown, reproduced itself in Carolina, New Jersey and New York (Galenson, 1996, p. 144). Similar processes were at work in other colonies of settlement (see Rueschemeyer, Stephens and Stephens, 1992, pp. 139-140, and McNaught, 1988, pp. 616, on Canada).

This situation is in stark contrast to other British colonies, for example in the West Indies. There the arrival of sugarcane in the early 1640s led to the creation of plantations with the use of African slaves. Local British planters did not lose control of their lands.
Galenson's picture of the early United States, supported by many other historical accounts, demonstrates the large impact of initial conditions in the colony on the institutions that the settlers built. Because there was very low population density and no way of extracting resources from indigenous peoples (for example existing tax or tribute systems), early commercial developments had to involve imported British labor. Moreover, relative to much of the colonial world the disease environment was benign, stimulating settlement. Indeed, the Pilgrim fathers decided to migrate to the U.S. rather than Guyana because of the very high mortality rates in Guyana (see Crosby, 1986, pp. 143144). Nevertheless, these same conditions made it impossible to profitably exploit such labor whose bargaining power forced elites to extend political rights and create equal access to land and the law. These forces were reinforced by the fact that at least in the northern US and Canada, plantation agriculture and slavery was not profitable.

\section{Lessons}

The history of Latin and North America shows how the distribution of economic resources and political power determines the institutions of society and how these factors join together in determining the subsequent path of inequality and growth. In both subcontinents Europeans enjoyed a huge technological advantage in weapons and thus were able to dominate indigenous peoples (Diamond, 1997) yet the type of societies that subsequently emerged depended a great deal on the initial conditions that the colonists found. Where there were large numbers of indigenous peoples and valuable natural resources, where plantation agriculture was profitable, and where the disease environment was relatively poor for Europeans, very hierarchical and authoritarian societies 
emerged where the mass of the population were exploited to the benefit of a narrow elite. This elite sustained itself in power even after independence in most places. From this situation of high political inequality emerged the very high levels of economic inequality that we see today in Latin America.

In North America a very different type of society emerged. Without indigenous people to exploit or resources to live off, and with slave plantations uneconomic in most places, colonies could only profit by attracting Europeans. Europeans, though they were not deterred by the disease environment, could only be made to work by creating incentives and giving them political rights. Though by the 18th century slavery had become an important institution in the southern US, it was relatively unimportant during the 17 th century when many crucial institutions were formed, and slaves never formed more than a small fraction of the total population, in contrast to the situation with respect to indigenous people in Mexico, Peru, Bolivia or Guatemala. In consequence a society dominated by Europeans emerged but with a much more equal distribution of resources and political power. This created a set of institutions much more favorable to growth and initiated the type of virtuous circle we discussed above.

\section{Other Historical Experiences}

One can clearly point to examples of rapid development which have been inegalitarian both politically and economically in the sense that the mass of the population have had little influence over the process, have often been seriously excluded or exploited and in consequence where equality of opportunity has been absent for the mass of the population. These experiences often occur when the elite themselves have good investment opportunities as was true in Argentina in the golden age from the 1870s to the 1920s, in Colombia in the half century after 1900, in Russia in the decades leading up to the First World War, and in the Côte d'Ivoire for the first two decades after independence (Widner, 1993). Though this is true I shall now use historical evidence to argue that such situations are rarely sustainable. This is for three reasons. First, the possibilities for sustained growth are by definition limited because institutions exclude the majority of the population from effectively investing. Second, in the rare situations where elites manage to create arrangements so that they can benefit directly from growth without the need to create good institutions more generally, such arrangements tend to be highly fragile and destroyed by shocks or crises. Finally, because bad institutions, since they generate large rents for those who control power, necessarily create power struggles which undermine growth.

In a sense one could claim that in a poor country elites always have good investment opportunities since even if they themselves are not involved in economic activities, they can benefit through taxation, corruption or extraction from the wealth created by others in a prosperous society. Nevertheless, historical experiences of development suggest that the promotion of rapid development by an elite anticipating the indirect benefits of prosperity is a rare occurrence (though we shall see that the experience of Indonesia after 1966 may be a partial example of this). This may be because it is impossible to promote investment by others when the distribution of power is skewed because those without power fear being expropriated, or because the political status quo is destabilized by growth.

One of the most interesting experiences of growth with fundamentally poor institutions is Argentina during the half century before 1930. Following independence from Spain Argentina was plunged into 50 years of civil 
Figure 6.

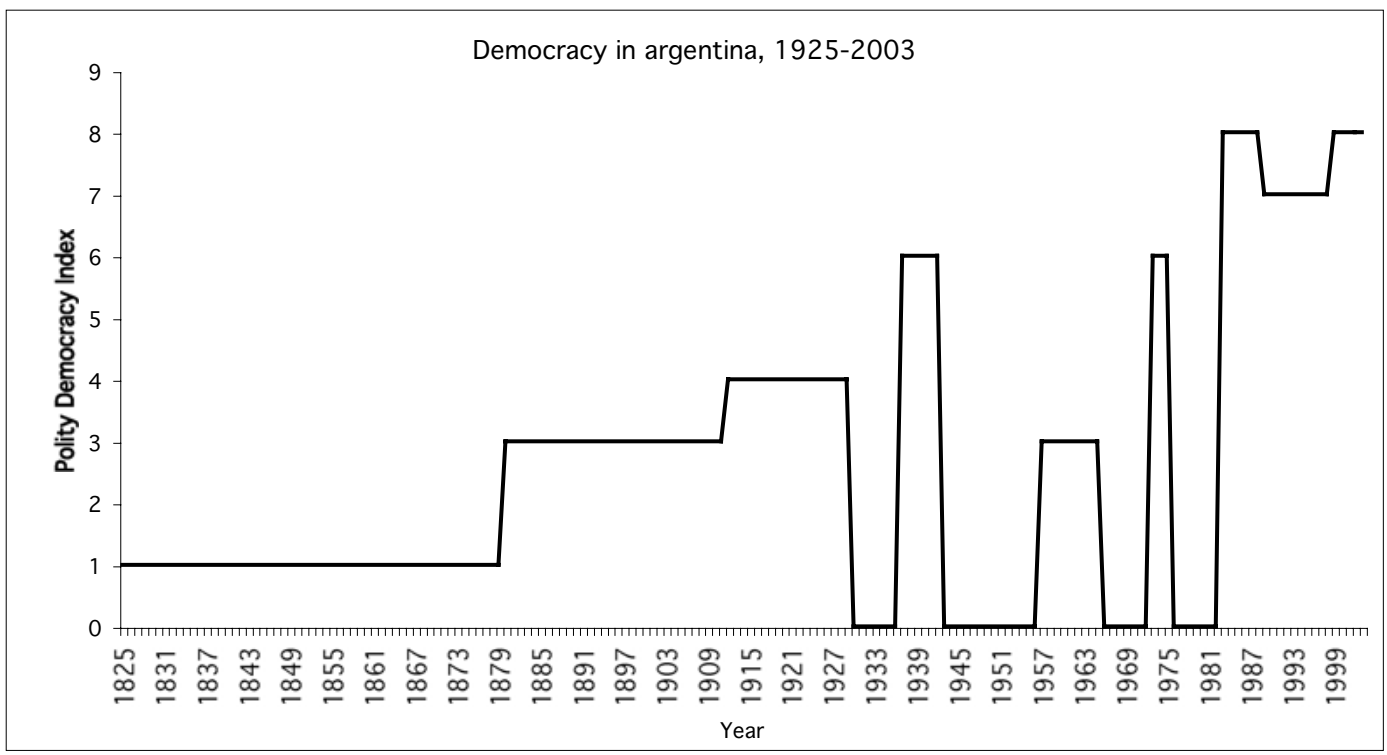

wars and conflicts over the control of the country. Many of these conflicts featured clashes between those in control of Buenos Aires and the littoral and those in the interior. These conflicts abated after the 1853 constitution and the subsequent presidency of Bartolomé Mitre which reached a compromise between the Pampas and the interior. Pampean mercantile and agrarian interests would be allowed to create a set of institutions to take advantage of the huge economic opportunities emerging on world markets, but the structure of the political rules, for example their over-representation in national political institutions (see Samuels and Snyder, 2001), guaranteed the interior provinces a large slice of the benefits.

Though the majority were excluded from the political system, with the property rights of the Pampean elite guaranteed, the economy boomed. Nevertheless, the huge rents created by this system began to cause conflict. In the 1890s the Radical Party emerged under Hipólito Yrigoyen and after organizing a series of revolts they were incorporated into the political system by the democratizing impact of the Sáenz Peña Law in 1912.

Though Yrigoyen was elected president in 1916, the traditional interests were confident that they could keep control of the polity and the economy. They were mistaken. The vote share of the Conservatives declined rapidly and the prospect of a Radical majority in the senate was a key factor behind the coup of 1930. Smith (1978, p. 21) notes "this situation contrasts sharply with that in Sweden and Britain ... where traditional elites continued to dominate systems after the extension of suffrage." From this point onwards political conflicts intensified with a stream of coups and re-democratizations which lasted until 1983. Having been amongst the richest countries in the world in the 1920s Argentina gradually regressed to 
the status of an underdeveloped country.

The type of oligarchic political equilibria that emerged in Argentina after 1853 emerged in Colombia after 1902 (we follow Mazzuca and Robinson, 2004). The main difference was that political interests were not articulated in terms of the Pampas versus the interior, but rather in terms of the two political parties, Liberal and Conservative. These parties, and the groups that had preceded their formation in the 1850s, had fought a long series of civil wars for power culminating in the War of 1,000 days from $1899-1902$. This war was by far the most costly and resulted in the independence of Panama which had previously been a state of Colombia. In response to this shock, and also to the realization of the huge economic benefits forgone by the disruption of the export economy, Colombian political elites devised a way to share the benefits from power in such a way as to avoid fighting for it. The basic way, enshrined in a constitutional amendment of 1905, was the introduction of the incomplete vote' in elections. This stipulated that the legislature would be chosen in such a way that the party that got the most votes would get $2 / 3$ of the seats with the remaining $1 / 3$ going to the runner up, no matter how many votes they got. This system was designed to give the Liberal Party, which had lost the war, 1/3 of the seats and $1 / 3$ of the power. In response to this agreement the coffee economy boomed as did the Colombian economy. With heavy elite interests in coffee the state invested in railroads and infrastructure.

Just as in Argentina however, this agreement could only buy stability and progress for so long. Economic development had generated new social groups and interests by the late 1920s and growing social unrest led the Liberals to introduce universal male suffrage in 1936 and the rudiments of a welfare state. In response to these changes electoral representation had been altered in 1929 with the introduction of proportional representation in an attempt to better balance the representation of different groups and to reflect the growing political support of the Liberal Party. The attempt by the traditional parties to incorporate the new interests destabilized the fragile balance of power that had existed since 1905 and by the 1940s the agreement began to come unstuck as the Liberal party became more populist and the Conservative more reactionary. The fighting began again in 1948 with the assassination of the Liberal leader Jorge Eliécer Gaitán. After 10 years of intense conflict and a military takeover, in 1958 the parties returned to the revised version of the formula, this time agreeing to share power $50-50$ for 16 years. Colombia's oligarchic equilibrium reproduced itself again, but in the context of continual conflict and a widening gap in economic performance between it and the developed countries.

\section{Lessons}

The experiences of Argentina and Colombia show that growth is possible with bad institutions under favorable circumstances when elites have very good investment opportunities and can manage to forge compromises. But the booms I have analyzed in this section ultimately unraveled. Even when elites, such as the agriculturalists of the Argentine Pampas face very good investment opportunities, growth cannot be sustained forever by agricultural export booms. When opportunities are less good, as they were in Colombia, growth will be less strong and indeed though Colombia began to grow after 1900 it never narrowed the gap between it and the United States or Western European nations. Moreover, the rents created by bad institutions create conflict without fundamental balances of power in society. 
This meant that democracy in Argentina after 1912 was unstable. The unchecked power of President Yrigoyen in the 1920s induced a coup in 1930, as that of Perón in the 1940s and 1950s did in 1955, and again in 1976 after this return from exile. Though institutional solutions can sometimes provide temporary solution to these conflicts, as they did in Argentina after 1853 and Colombia after 1905 , conflict ultimately reemerges. In Colombia this took the form of La Violencia a murderous civil war that raged from 1948 until the early 1960 s. $^{2}$ This political instability in both countries undermined investment incentives.

\section{Contemporary Development Experiences}

I now turn to the contemporary development experience. In so doing I shall emphasize one further mechanism that can lead to transitory development success. Elites may be forced by threats of social disorder to try to promote the prosperity of the majority of citizens. I shall argue however that, as with the case of elites who have a vested interest in prosperity, such situations rarely generate sustained prosperity unless they are institutionalized. Although the response of elites to social disturbances sometimes leads to solutions which permanently change the political equilibrium in a beneficial way, as may have happened with the agrarian reforms in South Korea and Taiwan in the late 1940s and early 1950s. In these societies commitments by elites which were initially contingent subsequently became institutionalized. More often however, the transitory ability of citizens to solve the collective action problem leads threats to dissipate without elites having to propose anything more than a transitory solution, as may have been the case in Indonesia under the New Order regime.

I now consider in more detail a sequence of case studies. I emphasize what lies behind successes and failures, and how often, while growth can occur without fundamental institutional change and without an institutionalized balance of political power, it tends to be transitory.

\section{Mauritius and Guyana}

Consider the histories of Mauritius and Guyana. In the 1960s as both countries moved towards independence they were both very poor societies dominated by sugarcane production and export. They had very similar histories, factor endowments, social and political cleavages and apparently similar institutions. If anything, Guyana, though slightly poorer, had better prospects, lying close to the large US market. Yet since independence Mauritius has become one of the most dynamic and successful LDCs. It successfully industrialized and maintained competitive democratic politics, while Guyana slumped into dictatorship and poverty.

The divergence between Mauritius and Guyana since independence is a fascinating example of economic and political divergence in apparently highly similar societies. Figure 7 shows the huge divergence in economic performance while Figure 8 shows that political institutions also diverged.

What can explain this? Both countries have very similar histories. Mauritius was taken from the French and Guyana from the Dutch during the Napoleonic wars (Bowman, 1991).

2. Another interesting example of such a temporary institutional solution to underlying conflict over institutions is the 1820 Missouri compromise in the US (Weingast, 1998). 


\section{Figure 7.}

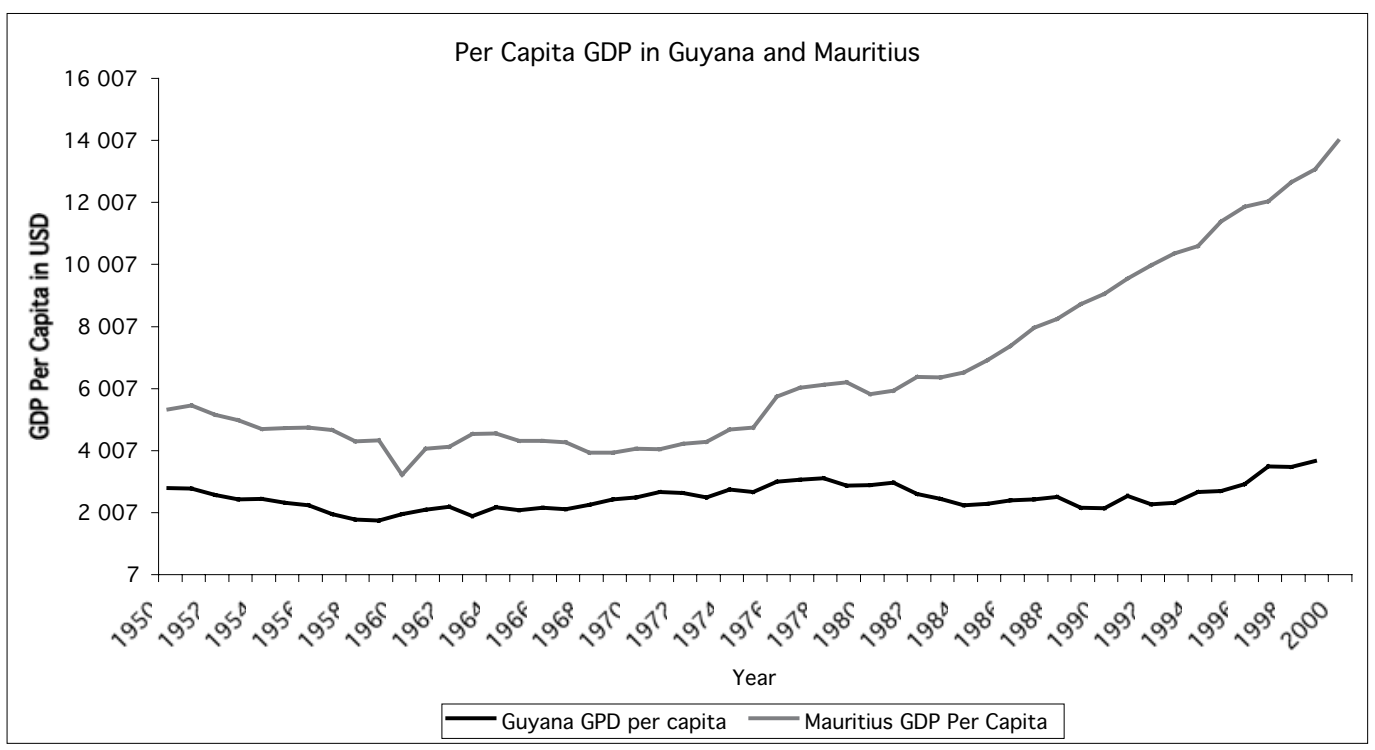

\section{Figure 8.}

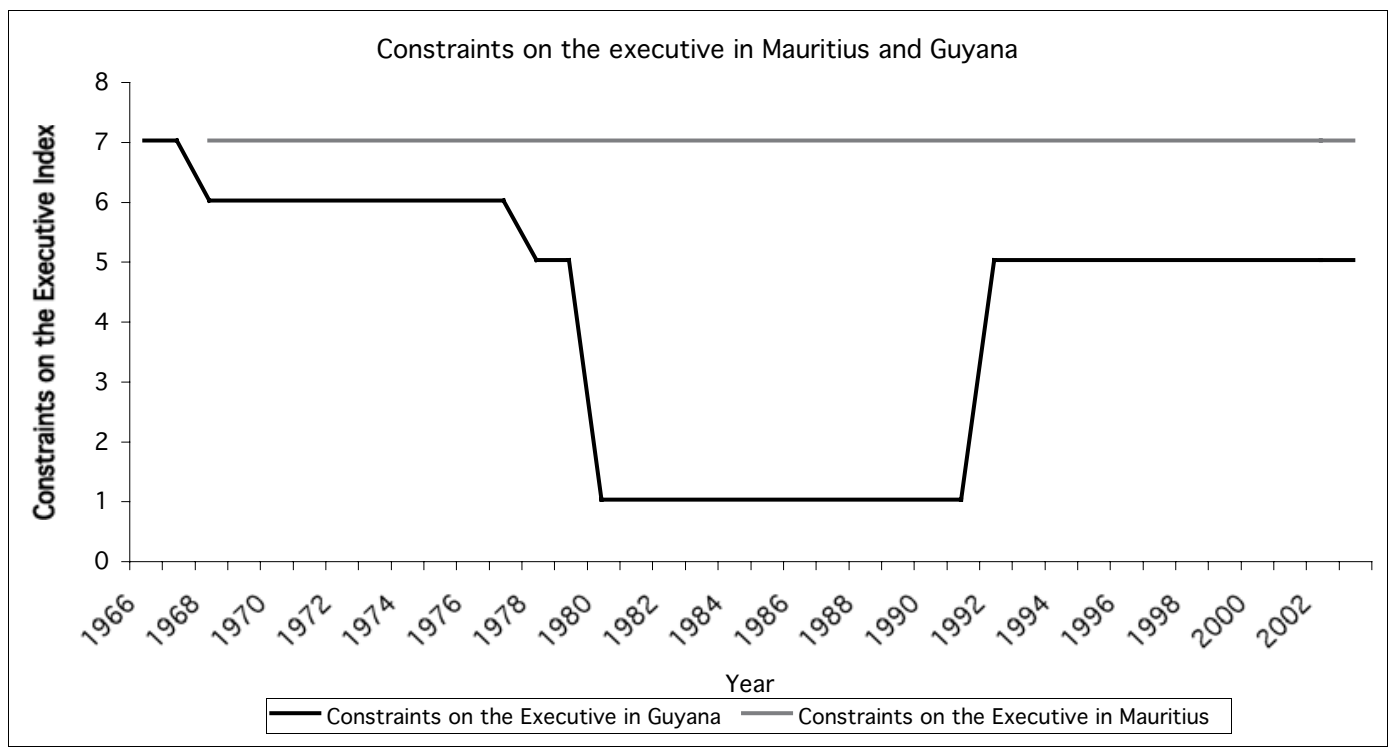


In the 19th century both developed important sugarcane economies and after the abolition of slavery in the British Empire in 1834, imported large numbers of indentured laborers from India. Both have a similar population structure with Indo-Guyanese and Indo-Mauritians forming the majority of the population with significant minorities of people of African, European and Chinese descent. After the Second World War, both colonies were moved by the British towards independence with early elections for democratic legislative assemblies being dominated by pro-independence political parties led by Seewoosagur Ramgoolam in Mauritius and Cheddi Jagan in Guyana. Both groups used extensive socialist rhetoric and proposed land reforms and relatively radical policies. Many of the political struggles with British administrators over postindependence institutions, such as the form of the electoral system, were fought over very similar issues. As independence arrived however, political forces re-formed into a situation where parties led by IndoMauritians and Indo-Guyanese faced parties which represented a coalition of the nonIndian population, led by Gaetan Duval in Mauritius and Forbes Burnham in Guyana.

Yet at independence politics and economics diverged. The Mauritian Labour Party won power initially and quickly abandoned its radical policies and by the early 1970 s investment in the export processing zone had begun. The political hegemony of the Labour Party was quickly contested by the emergence of a strong socialist party, the MMM (Mouvement Militant Mauricien) led by Paul Berenger and Dev Virahsawmy, and in response the Labour Party entered into a coalition with Duval and his PMSD (Parti Mauricien Social Democrate) and the previous opposition groups. However, the Labour Party quickly drew back from repression of the new political forces, allowed the MMM to contest the 1976 election, and instead adopted social policies, such as the provision of universal secondary education, to improve its popularity. The Labour Party also quickly dropped populist macroeconomic policies and in the late 1970s implemented a serious stabilization program under the IMF. The final test of Mauritian institutions was the election of an MMM government for the first time in 1982. Once in power the MMM also abandoned it's more radical policies and once the broad political consensus to good institutions became clear, the export processing zone boomed.

The contrast with Guyana is stark. The first election on the eve of independence was won by Burnham and his People's National Party in a coalition against Jagan's People's Progressive Party and he then maintained power by increasingly fraudulent means, finally changing the constitution in 1980 to make himself Executive President. He terrorized and assassinated opponents, most famously the radical economist and political activist Walter Rodney in 1980. The economic policies of Burnham's regime were a disaster. He expropriated the sugar plantations, creating highly inefficient state industries and he aggressively promoted the interests of his own party members through patronage, particularly in the civil service. The implied or actual threat to property and person led to a huge diaspora from the country of Indo-Guyanese, including most of the professional and middle class people. It was only in the 1990s that Guyana democratized and began to slowly recover from this legacy.

What can explain such divergent outcomes in such apparently similar circumstances? Two things appear to have been crucial. In Guyana, there were fewer constraints on the use of power and political conflict was more polarized because it came to be defined solely 
along ethnic lines. Though both countries started independence as democracies, in Mauritius this was a democracy where what the majority could do, or wanted to do, to the minority was limited, in Guyana it was not.

In Mauritius the British colonial state faced a powerful and homogeneous French planter class which did not leave the island after Mauritius was annexed to Britain in 1812. In the 1870 s when Britain was reducing the autonomy of colonial administrations, they were forced to create a legislative assembly in Mauritius. Though this was initially dominated by the planters, by the turn of the 20th century the first IndoMauritians were elected, a clear sign that the greater political autonomy of the island was allowing for a more open society with greater upward mobility of the former indentured laborers. In consequence, the power of the colonial state was checked, as was evident by the fact that during the 1960s Mauritian independence leaders were able to negotiate post-independence institutions closer to those that they wanted. This juxtaposition of different local interests and the weakening of the legacy of the colonial state gave rise to a relatively balanced distribution of political power in Mauritius. From this situation more fluid interests also emerged. Though ethnic identities were certainly important in politics, so were different cleavages, as is clear from the development of the MMM into a powerful political force and the coalition of Ramgoolam and Duval in the 1970s. In consequence politics became significantly less polarized than it might have been.

In Guyana there was no indigenous planter class checking the power of the colonial state since after the departure of the Dutch, and the plantations came to be owned by absentee British companies. There were far less forces to check the authoritarian tendencies of the colonial state. This was reinforced by British military intervention, promoted by the US, in 1953 to remove Jagan from power because of his socialist tendencies. Unlike in Mauritius, Guyanese politicians had far less ability to get what they wanted from the colonial state. This meant that there were fewer indigenous checks on the exercise of power, and the unfettered use of political power was the norm. The best example here is the electoral system. Britain imposed a proportional representation system on Guyana because they were afraid that the overrepresentation of large parties inherent in majoritarian systems would allow Jagan to win an absolute majority in the 1964 election (the PPP won $42.6 \%$ of the vote in the 1961 election). This system facilitated the rise to power of Burnham. In contrast, though the British tried to do the same thing in Mauritius, Mauritian political elites held out and forced a compromise, a system with relatively large electoral districts with the three politicians who got the most votes being elected and with the 8 'best losers' from the entire country also being elected to parliament. This system maintained elements of the majoritarian institutions that Mauritian leaders believed were essential to maintain governability of the country. Politics in Guyana also became completely defined along ethnic lines, pro or anti Indo-Guyanese. The likely reason for this is the previous evolution of the economy and dominant power of colonial interests left little room for the types of varied interests that emerged in Mauritius.

\section{Agricultural Pricing Policies in Africa}

Another important example which illustrates the connection between the distribution of political power and institutions comes from the seminal studies of regulation of prices in agricultural markets in Africa by Robert Bates (1981, 1989). Bates (1981) demonstrated that poor agricultural performance in Ghana, 
Nigeria and Zambia was due to government controlled marketing boards systematically paying farmers prices for their crops much below world levels. The marketing boards made surpluses which were given to the government as a form of taxation. As a result of this pernicious taxation, reaching up to $70 \%$ of the value of the crop in Ghana in the 1970 s, investment in agriculture collapsed as did output of cocoa and other crops. In poor countries with comparative advantage in agriculture such a situation mapped into negative rates of economic growth.

Why were resources extracted in this way? Though part of the motivation was to promote industrialization, the main one is to generate resources that could be either expropriated or redistributed to maintain power

"governments face a dilemma: urban unrest, which they cannot successfully eradicate through co-optation or repression, poses a serious challenge to their interests ... Their response has been to try to appease urban interests not by offering higher money wages but by advocating policies aimed at reducing the cost of living, and in particular the cost of food. Agricultural policy thus becomes a by-product of political relations between governments and urban constituents" (1981, p. 33)

In contrast to the situation in Ghana, Zambia and Nigeria, Bates $(1981,1989)$ showed that agricultural policy in Kenya over this period was much more pro-farmer. The difference was due to who controlled the marketing board. In Kenya, farmers were not smallholders, as they were in Ghana, Nigeria and Zambia, and concentrated landownership made it much easier to solve the collective action problem. Moreover, farming was important in the Kikuyu areas, an ethnic group closely related to the ruling political party, KANU, under Jomo Kenyatta (Bates, 1981, p. 122). Farmers in Kenya therefore formed a powerful lobby and were able to guarantee themselves high prices. Even though the government of Kenya engaged in land reform after independence

" $80 \%$ of the former white highlands were left intact and ... the government took elaborate measures to preserve the integrity of the large-scale farms ... [which] readily combine in defense of their interests. One of the most important collective efforts is the Kenya National Farmer's Union (KNFU) ... The organization ... is dominated by the large-scale farmers ... [but] it can be argued that the KNFU helps to create a framework of public policies that provides an economic environment favorable to all farmers" Bates (1981, pp. 93-94).

Bates concludes (p. 95) that in Kenya "large farmers ... have secured public policies that are highly favorable by comparison to those in other nations."

\section{Indonesia under the New Order Regime}

That some political equilibria which promote growth are transitory should already be evident from the discussion. Though Bates (1981) demonstrated why economic policies had been better in Kenya than Ghana in the 1960s and 1970s, this advantage did not survive the coming to power of Daniel Arap Moi in Kenya (Bates, 1989). The change in the ethnic basis of the regime, from Kikuyu to Kalenjin, undermined the coalition which had supported good agricultural policies, since the export farmers were not only large, but also predominantly Kikuyu. As a result economic performance declined precipitously 
in the 1980s and 1990s. The balance of power that sustained good policies in the 1970s was not sustained.

Another important example of successful growth with underlying bad institutions is Indonesia after the rise to power of Suharto and his New Order regime in March 1966. The economic performance of Indonesia since independence in 1950 had been highly unstable (see Bevan, Collier and Gunning, 1999) particularly under Sukarno's 'Guided Democracy' after 1957. In 1965 this regime collapsed in the context of economic crisis and an attempt by the Communist Party to mount a coup. The communists were ruthlessly suppressed by the army under Suharto and a new regime formed.

Central to this regime, called the New Order, was the promotion of rapid economic development, particularly in the rural sector where there was heavy investment in fertilizers, extension and credit programs, and infrastructure such as irrigation. The regime also invested heavily in education and launched ambitious school building programs which resulted after 1983 in universal primary education for boys and girls (Duflo, 2001). Relatively oil rich, Indonesia managed to allocate the windfalls of the 1970s to investment and escaped the familiar patterns of the Dutch disease. Macroeconomic policy was also very sound and when things began to go wrong and budget constraints soften, Suharto intervened to correct this. This was clear in the 1970s when he curtailed the activities of the government oil company Pertamina in 1975 (Bevan et al., 1999, pp. 251-253). The regime intervened again after oil prices fell in 1982 in order to force fiscal balance and during the 1980s undertook extensive reforms to reign in excessive corruption. The most famous instance of this is Suharto's issue of a presidential decree to sell off the customs to Swiss business interests in 1985 after it became apparent how endemic corruption was (MacIntyre, 2001c, p. 12). This and many other similar interventions had the effect of "curtailing corruption that had become sufficiently costly or disruptive to pose a serious threat to continued investor confidence" (MacIntyre, 2001c, p. 13). The economic success of Indonesia after 1966 even elevated it into the class of an Asian 'miracle economy' (World Bank, 1993).

There seems little doubt that the New Order regime was authoritarian and Suharto had wide discretionary powers in all dimensions of policy. If his power was constrained it is not clear by what. Though there were elections, the president's Golkar party was always assured of a solid majority and political opposition was closely controlled and restricted. The puzzle is why people invested in such an environment. At least two factors seem to have been important.

The first, on which all scholars concur, is that the social policies of the New Order were a direct response to the social disorders of 1965 and 1966 and the threat of rural communism. This was the driving factor behind the agrarian and educational policies which had such a huge positive impact not just on growth but on poverty alleviation and income distribution. McIntyre (2001b, p. 258) expresses the consensus view when he notes

"Suharto was determined to avoid a resurgence of rural radicalism and political instability of the sort that had gripped the country in the mid 1960s. In short, the success of these initiatives was a function of his keen political survival instincts."

More generally, Suharto recognized that economic growth was necessary to keep the regime in power and that to achieve this good economic policies had to be in place (Liddle, 
1991). This constraint induced him to delegate macroeconomic policy to technocrats and to respond to the oil booms wisely. It also led him to intervene to attempt to control corruption and excesses that would put in jeopardy the underpinnings of the regime (McIntyre argues, 2001b, p. 259).

Yet this constraint, real thought it was, at least in the 1960s and 1970s, is only part of the story about Indonesian growth. It is also clear that Suharto managed to create a system which, while it did not introduce good institutions, was able to induce investments and growth from which the regime could benefit. One of the secrets behind this appears to have been the role of Sino-Indonesian businessmen, the so called cukong entrepreneurs. Many firms and businesses were controlled by Indonesians of Chinese origin who were very marginal politically (as emphasized by Geertz, 1963). Suharto granted such businessmen monopoly rights and placed members of the military and his supporters on their boards of directors (Elson, 2001, pp. 194-201, 280-281, Rock, 2003, p. 14). Rock (2003, p. 10) argues "There is little doubt that the ... distortions in New Order microeconomic policies thwarted competition, rewarded cronies, and encouraged substantial investment in uneconomic projects." Yet they also generated wealth, economic growth and rents for the regime. It was precisely the political marginality of the cukong entrepreneurs that made them an attractive business partner for the regime.

"The Indonesian government was indisputably the senior partner with an uncontested ability to both grant ... privileges (rents or rights) to cukong entrepreneurs and to protect the economic rights so granted. Because [they] were a scorned ethnic minority totally lacking in political power, they had few opportunities to either challenge the government's economic priorities or to turn this exchange ... into simple growth retarding rent-seeking behavior. They also had to suspect that their continued access to privileges depended on them investing wisely to grow the economy" (Rock, 2003, pp. 36-37).

Thus Suharto entered into relationships with Chinese businessmen because their prosperity could not be a threat to his regime and also because their lack of political power meant he could discipline them if they failed to invest. Chinese businessmen did invest because, even though they must have been concerned about state predation, they were granted huge rents and they also understood that the regime needed them to generate wealth.

\section{Lessons}

In Mauritius property rights have been secure and the country has experienced open democratic politics. There has been intensive investment in education and free access into profitable investment opportunities. This is illustrated most clearly in the case of the export processing zone. In Guyana the opposite was true in the 1970s and 1980s. The puzzle is why institutions have been so good in one case and so bad in other given such apparently similar histories and circumstances.

However, these cases make sense looked at in more detail. The colonial history of Mauritius diverged from that of Guyana in significant ways which allowed the development of a stronger domestic political society. This was able to resist the colonial state more effectively and it ultimately generated both a more egalitarian distribution of political power where the power of elites was checked, and a less polarized structure of political conflict. In Guyana however, unlike in Mauritius or Kenya, there was no powerful 
domestic interest group with a vested interest in opposing the colonial state or which was able to block the state from expropriating land and other assets after independence. The use of power was relatively unconstrained and politics highly polarized along ethnic lines.

Nevertheless, the development of good institutions in Mauritius and bad ones in Guyana were not just the outcome of historical circumstances. Individual decisions were also important in both these cases. Critical decisions were made in Mauritius by Seewoosagur Ramgoolam, the Prime Minster and head of the Labour Party in the 1970s and by Paul Berenger and the leaders of the MMM when they initially came to power in 1982. Both parties abandoned policies to implement land reforms which might have seriously undermined property rights, and the Labour Party pulled back from unconstitutional measures to control political opposition in the 1970s. Moreover, the modern choice of institutions, particularly the electoral system in the 1960 s was clearly important in determining how political conflicts were resolved, with important implications for subsequent economic development.

In Bates's work on African agriculture we again saw how the distribution of political power was crucial in determining institutional outcomes and we saw in the case of Kenya that unless this was institutionalized, good outcomes were not sustainable.

The experience of Indonesia shows that growth is possible with underlying bad institutions when elites can credibly make a contingent commitment to make institutions better, and also when they manage to forge mechanisms for indirectly benefiting from encouraging the investment opportunities of others. The acceleration of growth after 1966, and particularly the pro-poor aspect of growth, was clearly driven by the threat of communism and rural social disorder. The spillover from the conflicts of 1965 and 1966 , was a redistribution of power towards the rural sector, in the same way that the collapse of the cultural revolution in China, which we shall discuss in the next section, redistributed power away from the Communist Party. In both cases sustained growth was necessary for the political survival of the regime. Yet the redistribution of power that occurred in Indonesia was not institutionalized and turned out not to be completely permanent. Moreover, it did not force the New Order regime to improve institutions outside of the rural and educational sectors though the connection between promoting economic development and social order may well have helped the government to sustain its relationship with the cukong entrepreneurs. When the constraints which had induced the economic policies of the new order regime relaxed in the 1990s it appears to have been more and more difficult to avoid a massive and debilitating upsurge in corruption and rent seeking. Moreover, the type of collusive agreement that the state managed to forge with the Sino-Indonesian entrepreneurs appears to have been very fragile. It rested on shared expectations about the future longevity of the relationship which clearly deteriorated with Suharto's failing health (Fisman, 1991) and it could not survive the 1997 crisis (MacIntyre, 2001a, Stern, 2003).

\section{Institutional Transitions}

So far I have examined cases which illustrate the mechanisms which lead to the creation of good institutions and sustained prosperity. These centrally involve institutions which allow for the equality of opportunity and behind such a set of institutions lies a relative balance of economic resources and political power. Historically, such institutions emerged 
in some societies but not others. Though systems of institutions often tend to reinforce one another and persist for long periods of time, they also change. Countries with inegalitarian distributions of resources and political power become more egalitarian and democratic, and previously powerless people gain in power and influence. Countries which had bad institutions experience improvements. We saw such processes at work in the case of Mauritius. Though sometimes institutions are created by deus ex machinas, such as colonialism or military conquest, often can evolve via good decisions, virtuous paths and through the intrinsic dynamics of the development process, again as in Mauritius. It is also possible that even what we have classified as transitory conditional solutions lead to permanent change because the growth process itself unleashes transformations which induce beneficial changes in institutions. This is the message of modernization theory (e.g., Lipset, 1959) and we suggested that this is precisely what may have happened in South Korea.

The biggest challenge is to understand processes of change and to distil from them lessons about how poor societies can undergo beneficial institutional transitions. This does not appear to have happened in Argentina or Indonesia, at least not yet, but it did happen in Britain in the $17^{\text {th }}$ and 19th centuries and it happened in Mauritius and South Korea in the 20th century. Though we argued that features of Mauritian history help to explain its institutional trajectory, good decisions were also made in the 1960s and 1970s to respect democratic rights and freedom of expression and also property rights. In consequence the economy boomed and this undoubtedly led to a greater commitment to these institutions and a heightened reticence to undermine them. In this section I discuss in detail two important transitions. Those of early modern
Europe and that which may have happened in China in the last 20 years.

In the late Middle Ages, around 1500, most European countries were ruled by absolute monarchs whose powers were endowed by God, and were highly hierarchical feudal societies. The most prosperous places, such as the Italian city states of Venice, Genoa and Florence, were those that had escaped feudalism and were ruled by republican governments which strongly represented mercantile interests. The Netherlands too had escaped intense feudalism and was relatively prosperous, but was part of the autocratic Hapsburg Empire. Nevertheless, the differences in income between the most and the least prosperous places was relatively small. After 1500 this picture began to change rapidly, first the Netherlands and then Britain became much more prosperous than the rest of Europe and the Mediterranean world went into decline. Though measuring prosperity in the early modern period in difficult, there is a wide consensus amongst historians about what happened and it can be summed up by looking at patterns of urbanization. Acemoglu, Johnson and Robinson (2002, 2005) argue that urbanization is a very useful proxy for prosperity in the era before national accounts. Figure 9, shows historical urbanization defined as the proportion of the population living in urban areas with at least 5,000 people.

This picture shows that in 1300 Italy was the most urbanized society but it was overtaken by the Netherlands around 1500 . In the 17th century it was Britain that began to urbanize the most rapidly taking over from the Netherlands as the most urbanized country in the early 19 th century.

As North and Thomas (1973) argued, the most plausible explanation for these patterns is the emergence of constitutional government in the Netherlands and Britain. Figure 10, 
Figure 9.

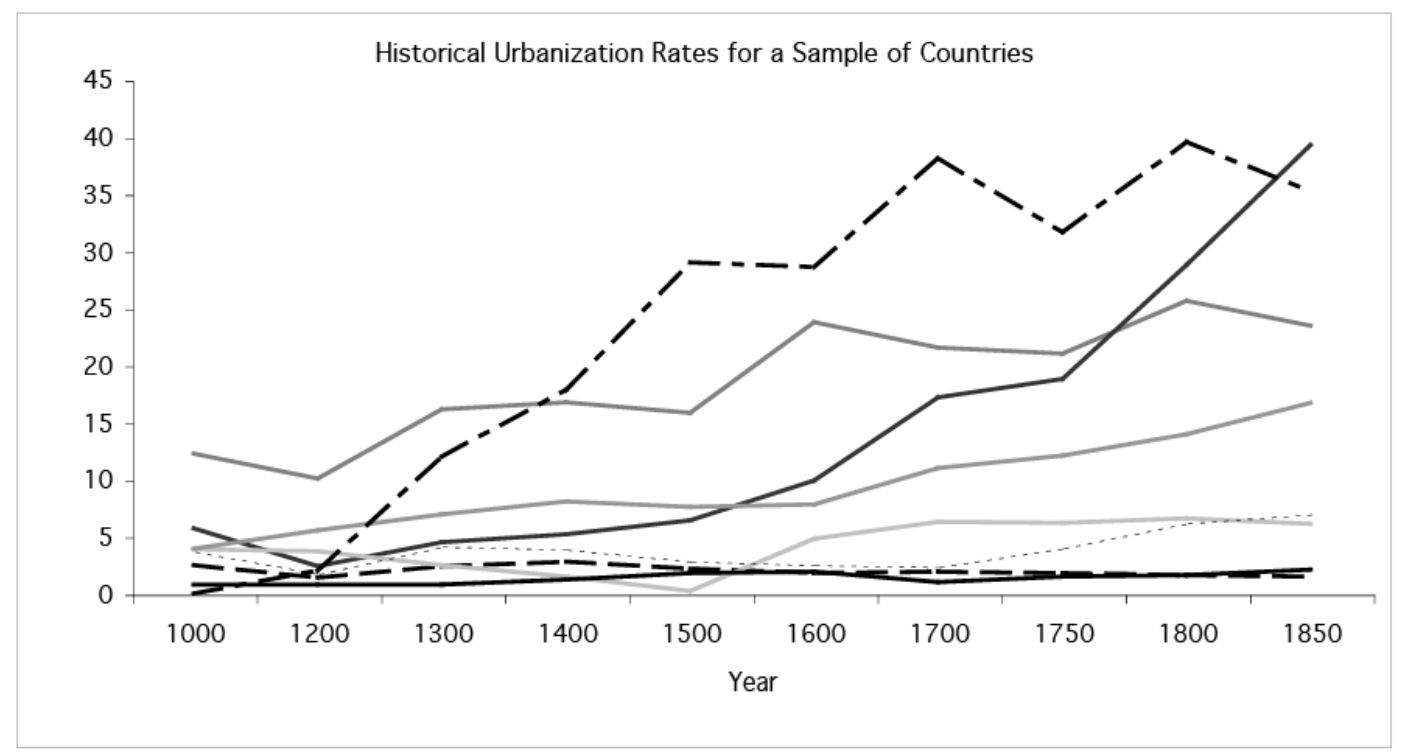

Figure 10.

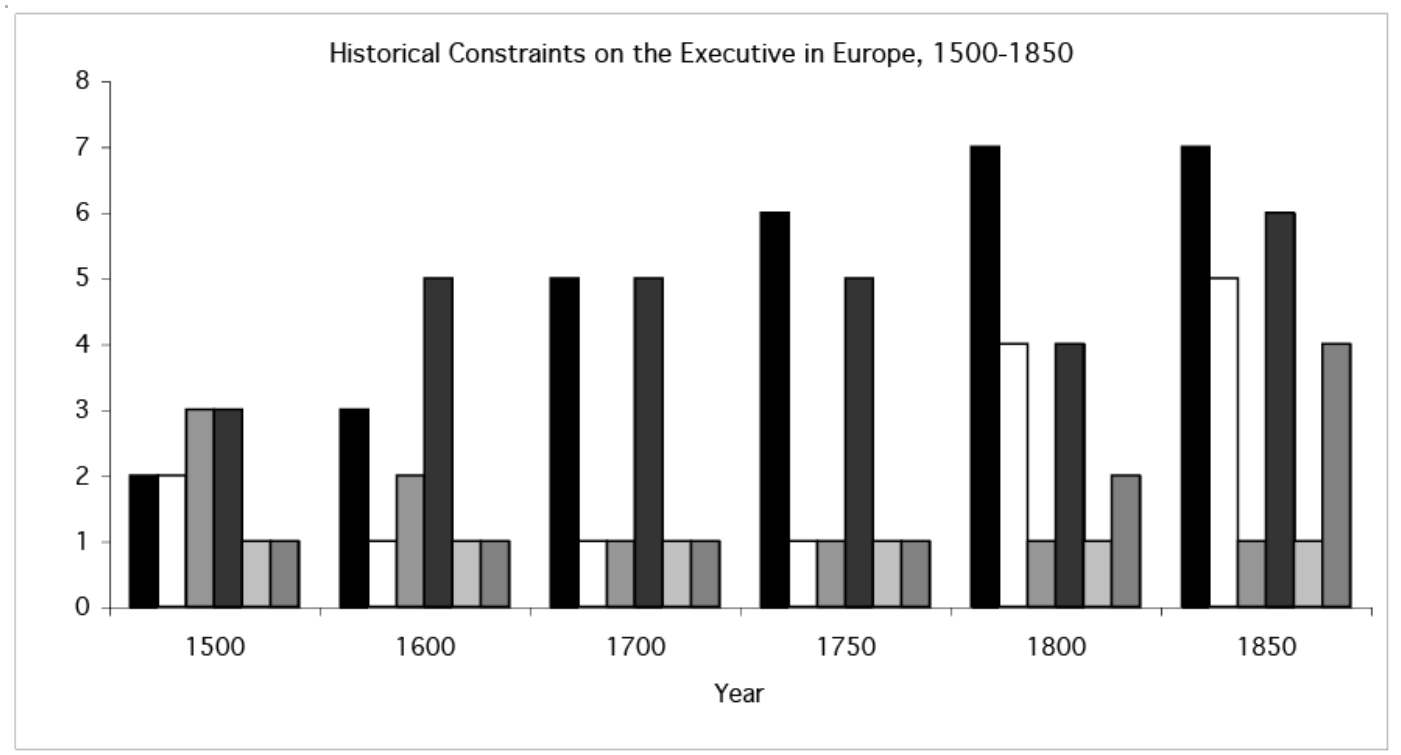




\section{Figure 11.}

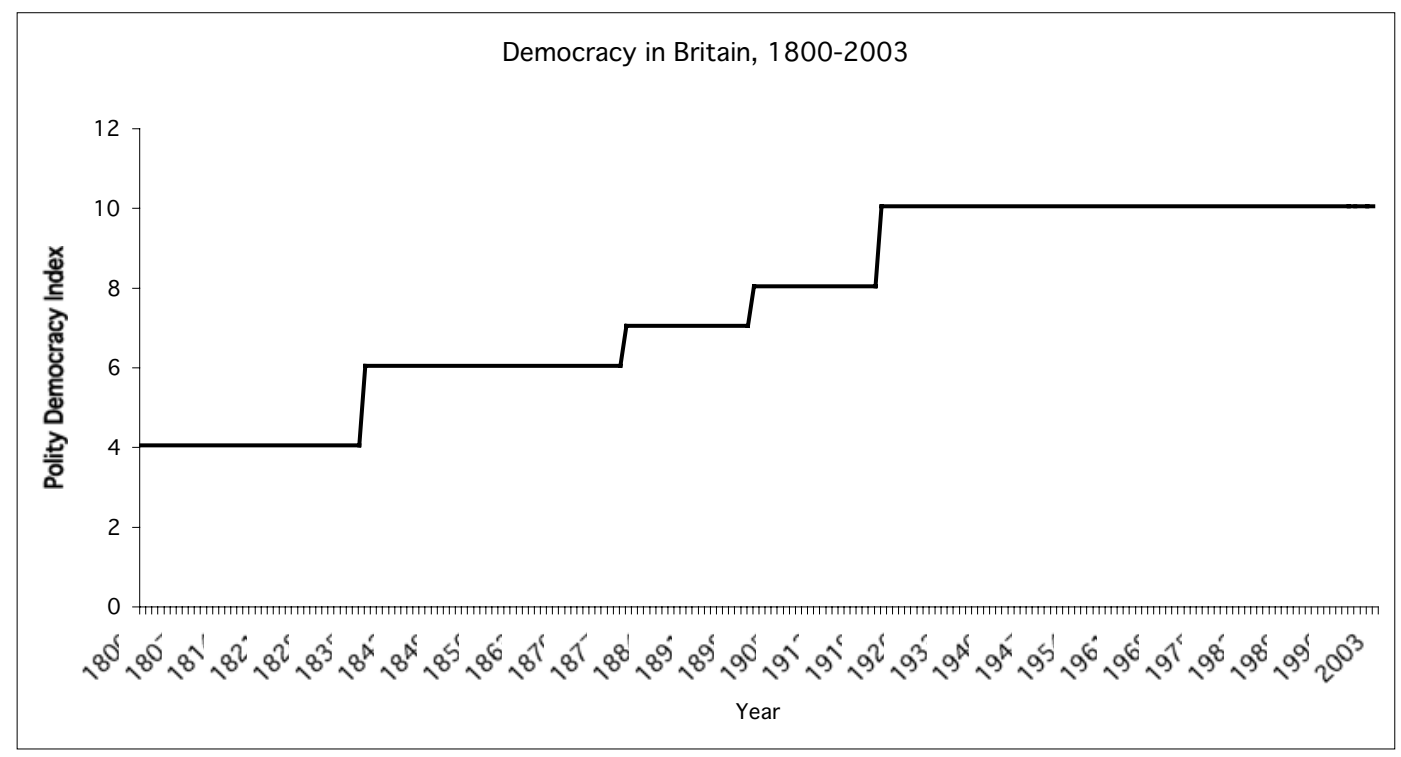

using data from Acemoglu, Johnson and Robinson (2005) shows the evolution of constraints on the executive over this period.

This figure strongly suggests that diverging prosperity within the early modern period was tied to the evolution of political institutions. This conjecture is substantiated by the standard account of the evolution of institutions in Britain culminating the in Glorious Revolution of 1688 (North and Thomas, 1973, North and Weingast, 1989, O'Brien, 1993, Acemoglu, Johnson and Robinson, 2005). The proximate reason for these changes and the improvement in institutions was a change in the distribution of resources and political power. Indeed, there was a virtuous circle of changes in institutions, the distribution of resources and power and subsequent changes in institutions. These changes included the collapse of feudalism, serfdom and the movement towards a free labor market (Brenner, 1976), changes in land distribution and the commercialization of agriculture (Tawney, 1941, Moore, 1966) and the development of inter-oceanic commerce (Acemoglu, Johnson and Robinson, 2005).

Yet the political system was at root oligarchic after 1688. Property rights were secure because those with a vested interest in them now held power (Stasavage, 2003) although there is also evidence that the institutional system that emerged protected property rights for a much broader crosssection of society (Thompson, 1975). It was further changes in the distribution of political power towards greater political equality that played a key role in sustaining Britain's development path and eventually delivering a more egalitarian society. The most obvious evidence comes from Figure 11 which shows the evolution of the Polity IV democracy score after 1800 . This index goes from 0 to 10 , with 10 being the most democratic score. 
Figure 12.

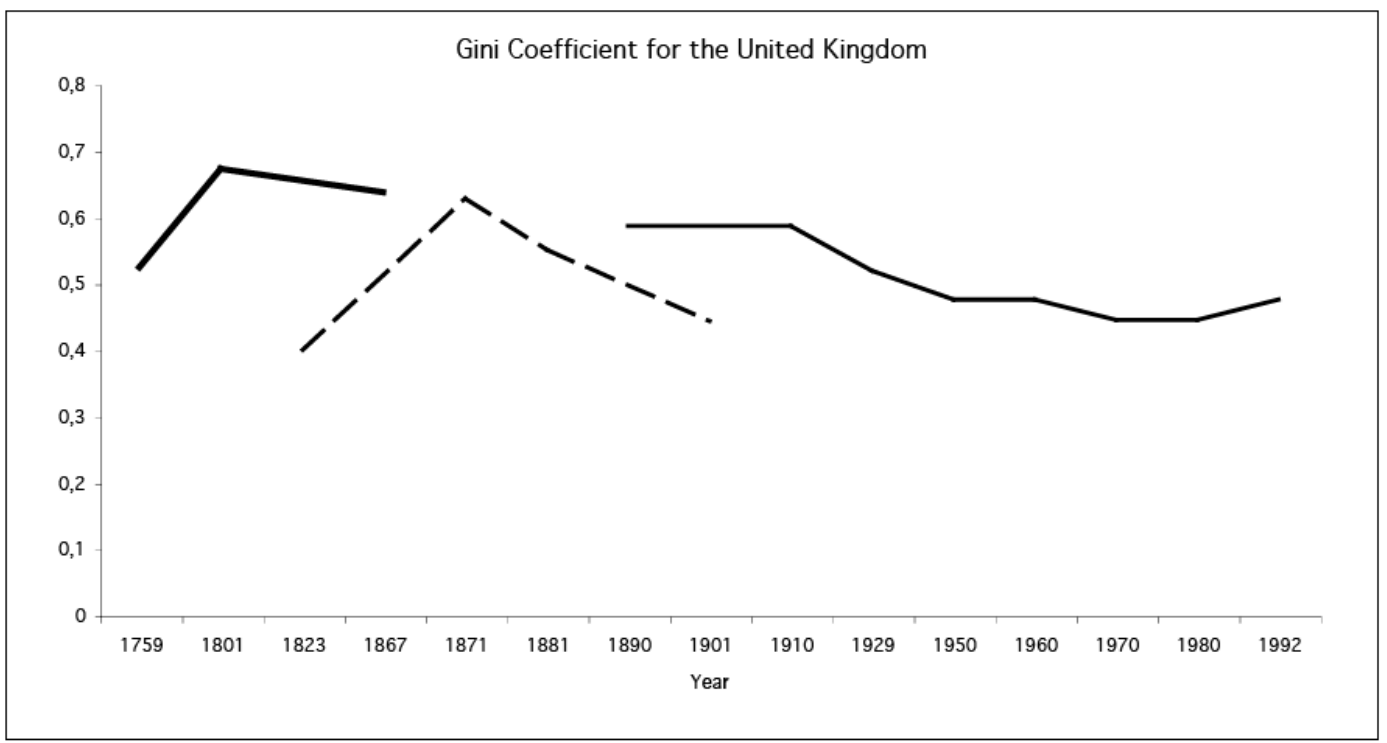

The picture vividly demonstrates the process of democratization that overtook British society after 1832 (see Acemoglu and Robinson, 2005). Even though Britain was a constitutional regime, it was very limited from a democratic point of view in 1800 . Before the first reform act of 1832 set in motion a series of political liberalizations that culminated in full democracy in 1918, less than $10 \%$ of adult males could vote. The proximate reason for these changes seems to have been the effect of early industrialization and urbanization on the ability of the disenfranchised to contest the power of political elites (see Thompson, 1963, Tilly, 1995, Tarrow, 1998). The changes depicted in Figure 11 were the outcome of a series of strategic concessions by political elites to avoid social disorder (Acemoglu and Robinson, 2000, 2004). Nevertheless, prior to democratization in Britain political power was effectively constrained and the Polity measure of constraints on the executive gives Britain a perfect score throughout the $19^{\text {th }}$ century.

While the political system of the 18th century was consistent with the encouragement of individual initiative, invention and the initiation of the industrial revolution in Britain, sustained long-run growth necessitated broad investment, particularly in human capital. Such institutions had to wait for relatively mass democracy to arrive after 1867 (Lindert, 2003, 2004).

The types of political reforms that took place in 19th century Britain led to economic institutions that clearly influenced income distribution. Most obviously this was the promotion of education after 1867 , but the same period also saw extensive labor market reforms which strengthened the bargaining power of labor and also led to the rise of the Labour Party. After 1906 the Liberal government of Herbert Asquith also began to introduce the basics of a welfare state which 
was further extended by the Labour government after 1945. As Britain began to adopt a set of institutions that promoted prosperity, it was still a highly unequal society, and inequality almost certainly increased until the early or middle of the 19th century. Figure 12 shows data on the historical evolution of the Gini coefficient in England from Lindert and Williamson (1982, 1983), Williamson (1985) and Bourguignon and Morrisson (2002). Though precise measures of inequality differ depending on the sources inequality appears to have risen until the early and perhaps the mid 19th century (other data on real wages and real rental rates on land supports this claim, see O'Rourke and Williamson, 2005). After about 1870 there is wide consensus that inequality fell substantially for the next century.

The fall in inequality after 1870 is closely correlated with the Second Reform Act of 1867 which was the first reform which really expanded voting rights to working people. Other available evidence from the 19th and early 20th centuries is consistent with this pattern (Acemoglu and Robinson, 2005, Chapter 3). This is in fact a relatively general result of democratization. When democracy enfranchises the relatively poor the poor are usually able to use democracy to tilt economic institutions and the distribution of income in society in their favor (Li, Squire and Zou, 1998, Rodrik, 1999).

\section{China}

The experience of economic development in China since 1978 gives another interesting example where a relatively equal distribution of resources and a balance of political power has been crucial in explaining why growth has occurred, but where this balance has evolved over time and has plausibly been permanently institutionalized. If the structure of political power in England in the early 17th century did not provide for the security of property rights necessary for investment and the development of good institutions, the situation with respect to the rule of the Chinese Communist Party (CCP) seems much worse. Not only is the power of the CCP apparently unchecked or constrained by political institutions, but it also had the legacy of a sometimes virulent anti-capitalist ideology. Since rapid growth has gone alongside the continued dominance of the CCP it appears difficult to argue that this is a situation where an equal distribution of power has been important in inducing good institutions. Moreover, one could doubt whether institutions have even been good in the sense described earlier. Yes, there has been relatively free entry into profitable economic opportunities, but whether or not private property rights exist and are stable is unclear and there is no independent judicial system to act as an independent arbiter.

Yet the experience in China is consistent with the thesis of this chapter. Many scholars agree that after the trauma of the cultural revolution, the death of Mao in 1976, and the recognition by Deng Xiaoping and those who assumed power after 1978 that China had fallen disastrously behind economically, there was a strong desire amongst leaders of the CCP to promote growth (see Perry and Wong, 1985, Harding, 1987, Shirk, 1993). Particularly threatening to Chinese leaders was that by this time the extraordinary economic success of Taiwan had become apparent. The quandary was how to promote growth without loosening the control of the party. How could people be induced to invest? Deng understood that reform without some change in the distribution of power was infeasible, but he realized that this could be achieved under the existing regime. In particular he realized that "he could use local officials as an effective counterweight to the 
centre without changing the political rules of the game" (Shirk, 1993, p. 12). In 1978 the Chinese state was much less centralized than the Soviet state had been and a great deal of the economy was already run by local governments. A crucial process of further political decentralization took place and Montinola, Qian and Weingast (1995, p. 5152) argue that

"China's political decentralization shares much in common with Western federalisms. The modern Chinese system includes a division of authority between the central and local governments. The latter have primary control over economic matters within their jurisdictions. Critically, there is an important degree of political durability built into the system".

In consequence "political reform in China has placed considerable limits on the discretion of the central government" (Montinola, Qian and Weingast, 1995, p. 50). Alongside political reform went economic reform: "For almost 20 years, reform in China has proceeded through the gradual reassignment of specific property rights from higher government agencies to lower government agencies, or from government agencies to enterprises, managers, families, or individuals" (Walder and Oi, 1999, p. 7). The strengthening of the powers of local governments and their direct economic interest in promoting local economic development was what got the Chinese economy moving. Central to this initial process were the rapid expansion of Township Village Enterprises whose investments were secure precisely because of the political power of local governments (Oi, 1992, Putterman, 1995, Che and Qian, 1998, Qian, 2003).

Has this process led to a permanent change in the distribution of power? The answer to this appears to be yes. Tellingly after the Tiananmen Square protests were suppressed in 1989 there was an attempt by some senior members of the CCP to recentralize power, but state governors refused and got their way (Montinola, Qian and Weingast, 1995, p. 68). Montinola, Qian and Weingast (1995, p. 71) conclude that "rival power centers have emerged in China. Local governments, particularly those in areas with the largest growth, now have substantial independent sources of revenue, authority, and political support."

The growth process has reinforced the distribution of power, strengthening other forces outside the CCP. Lying behind these processes is another more subtle change in the balance of political power. The aftermath of the cultural revolution undermined much of the support for the CCP amongst the populace. In order to maintain social order the regime needed to deliver economic benefits since it could no longer rely on ideological support. The durability of the regime therefore came to reply on continued prosperity. This phenomenon is important because it can also help to explain why people anticipated property rights were secure: people understood that the regime could not risk undermining investment and growth by expropriating wealth. This type of constraint played important roles in the modern growth experiences of South Korea and Indonesia as we have seen.

\section{Conclusion}

In this essay I have proposed a few simple principles which I believe go a long way to unifying very different development experiences both in the historical and the contemporary world. There is little disagreement amongst scholars that basic institutions such as security of property rights 
and equality before the law are a key to prosperity. Since talent and ideas are widely distributed in the population, a prosperous modern society requires the great mass of people to have incentives and it requires a state which can and will provide key complementary inputs and public goods. It therefore requires an underlying set of institutions that generate equality of opportunity for individuals and assures accountability of politicians to all.

But why do some societies have such institutions and not others? I have argued that underpinning institutions which promote prosperity is a relatively egalitarian distribution of political power. Institutions clearly have distributional effects and bad institutions often arise because they benefit some group or elite. In consequence, good institutions arise when checks are placed on the power of elites and when the balance of political power becomes more equal in society. Often, equality of political power is underpinned by economic equality and this connection gives rise to the possibility of both virtuous and vicious circles.

Growth can certainly occur in societies where these conditions do not apply. Nevertheless, the preponderance of evidence suggests that such growth is unsustainable. I showed how this perspective is consistent with historical narratives, basic patterns in the cross-country data and also more careful causal empirical work on the sources of prosperity.

The crucial issue for the promotion of development is how poor societies can improve their institutions and move onto a dynamic path towards a virtuous circle of equity and prosperity. Obviously the organization of society is highly persistent, but we have also examined many cases of transitions to better equilibria. Sometimes, as in early modern Britain, this is because economic changes lead to changes in the distribution of power which promote a more equitable society and better institutions. In other times, as in South Korea and Indonesia, regimes are forced by external or internal threats to change the trajectory of their society in ways which then become institutionalized. In some cases, in the cases of Mauritius and Botswana, leaders make good decisions that lead to reinforcing paths of better institutions and development.

\section{References}

Acemoglu, Daron, Simon Johnson and James A. Robinson (2001) "The Colonial Origins of Comparative Development: An Empirical Investigation", American Economic Review, 91, 1369-1401.

Acemoglu, Daron, Simon Johnson and James A. Robinson (2002) "Reversal of Fortune: Geography and Institutions in the Making of the Modern World Income Distribution," Quarterly Journal of Economics, 118, 1231-1294.

Acemoglu, Daron, Simon Johnson and James A. Robinson (2005) "The Rise of Europe: Atlantic Trade, Institutional Change and Economic Growth" American Economic Review, 95, 546-579.

Acemoglu, Daron, Simon Johnson and James A. Robinson (2006) "Institutions as a Fundamental Cause of Long-Run Growth," in Philippe Aghion and Steven Durlauf eds. Handbook of Economic Growth, Amsterdam; North-Holland.

Acemoglu, Daron and James A. Robinson (2000) "Why Did the West Extend the Franchise? Growth, Inequality and Democracy in Historical Perspective", Quarterly Journal of Economics, 95, 1167-1199.

Acemoglu, Daron and James A. Robinson (2005) Economic Origins of Dictatorship and Democracy, New York; Cambridge University Press.

Bakewell, Peter J. (1984) Miners of the Red Mountain, Albuquerque; University of New Mexico Press.

Banerjee, Abhijit V. and Andrew F. Newman (1993) "Occupational Choice and the Process of Development," Journal of Political Economy, 101, 274-298.

Bates, Robert H. (1981) Markets and States in Tropical Africa, University of California Press, Berkeley CA. 
Bates, Robert H. (1989) Beyond the Miracle of the Market, New York; Cambridge University Press.

Bevan, David L., Paul Collier and Jan Willem Gunning (1999) The Political Economy of Poverty, Equity and Growth: Nigeria and Indonesia, New York; Oxford University Press.

Bourguignon, François and Christian Morrisson (2002) "Inequality among World Citizens, 1820-1992," American Economic Review, 92, 727 - 744.

Bowman, Larry W. (1991) Mauritius: democracy and development in the Indian Ocean, Boulder, Colo., Westview Press.

Brenner, Robert (1976) "Agrarian Class Structure and Economic Development in Preindustrial Europe" Past and Present, 70, 30-75.

Cardoso, Ciro F.S. (1991) "The Liberal Era, 18701930," in Leslie Bethell ed. Central America Since Independence, Cambridge University Press, Cambridge UK.

Che, Jiahua and Yingyi Qian (1998) "Insecure Property Rights and Government Ownership of Firms," Quarterly Journal of Economics, 113, 467-496.

Coatsworth, John H. (1993) "Notes on the Comparative Economic History of Latin America and the United States," in Development and Underdevelopment in America: Contrasts of Economic Growth in North and Latin America in Historical Perspective edited by W.L. Bernecker and H.W. Tobler, Berlin; de Gruyter.

Cole, Jeffrey A. (1985) The Potosi Mita, 1573-1700: Compulsory Indian Labor in the Andes, Palo Alto, CA, Stanford University Press.

Craven, Wesley F. (1932) Dissolution of the Virginia Company; the failure of a colonial experiment, Gloucester, Mass.; P. Smith.

Crosby, Alfred (1986) Ecological Imperialism: The Biological Expansion of Europe 900-1900, Cambridge University Press, New York NY.

Diamond, Jared M. (1997) Guns, Germs and Steel: The Fate of Human Societies, W.W. Norton \& Co., New York NY.

Duflo, Esther (2001) "Schooling and Labor Market Consequences of School Construction in Indonesia: Evidence from an Unusual Policy Experiment," American Economic Review, 91, 795-813.

Elson, Robert E. (2001) Suharto: a political biography, New York; Cambridge University Press.

Engerman, Stanley L. and Kenneth L. Sokoloff (1997) "Factor Endowments, Institutions, and Differential Paths of Growth among New World Economies," in Stephen H. Haber ed. How Latin America Fell Behind, Stanford University Press, Stanford CA.
Fisman, Ray (2001) "Estimating the Value of Political Connections," American Economic Review, 91, 1095-1102.

Galenson, David W. (1996) “The Settlement and Growth of the Colonies: Population, Labor and Economic Development," in Stanley L. Engerman and Robert E. Gallman eds. The Cambridge Economic History of the United States, Volume I, The Colonial Era, Cambridge University Press, New York.

Geertz, Clifford (1963) Peddlers and Princes; social change and economic modernization in two Indonesian towns, Chicago; University of Chicago Press.

Haber, Stephen H. (2001) "Political Institutions and Banking Systems: Lessons from the Economic Histories of Mexico and the United States, 17901914," Unpublished, Department of Political Science, Stanford University.

Haber, Stephen H. and Noel Maurer (2004) "Related Lending and Economic Performance: Evidence from Mexico," Unpublished, Department of Political Science, Stanford University.

Hall, Robert E. and Charles I. Jones (1999) "Why Do Some Countries Produce so much more Output per Worker than Others?" Quarterly Journal of Economics, 114, 83-116.

Harding, Harry (1987) China's Second Revolution: Reform after Mao, Washington DC; The Brookings Institution.

Hemming, John (1970) The Conquest of the Incas, New York; Harcourt, Brace \& Company.

Knack, Steven and Philip Keefer (1995) "Institutions and Economic Performance: Cross-Country Tests using Alternative Measures," Economics and Politics, 7, 207-227.

Klarén, Peter Flindell (2000) Peru: Society and Nationhood in the Andes, New York; Oxford University Press.

Kupperman, Karen O. (1993) Providence Island, 16301641: the other Puritan colony, New York; Cambridge University Press.

Lang, James (1975) Conquest and Commerce: Spain and England in the Americas, Academic Press, New York NY.

Li, Hongyi, Lyn Squire and Heng-fu Zou (1998) "Explaining International and Intertemporal Variations in Income Inequality," Economic Journal, 108, 26-43.

Liddle, R. William (1991) “The Relative Autonomy of the Third World Politician: Soeharto and Indonesian Economic Development in 
Comparative Perspective," International Studies Quarterly, 35, 403-427.

Lindert, Peter H. (2003) "Voice and Growth: Was Churchill Right?" Journal of Economic History, 63, 315-350.

Lindert, Peter H. (2004) Growing Public: Social Spending and Economics Growth since the Eighteenth Century, Two volumes. Cambridge University Press, 2004.

Lindert, Peter H. and Jeffrey G. Williamson (1982)

"Revising England's Social Tables, 1688-1812,"

Explorations in Economic History, 19, 385-408.

Lindert, Peter H. and Jeffrey G. Williamson (1983)

"Reinterpreting Britain's Social Tables, 1688-1913,"

Explorations in Economic History, 20, 94-109.

Lipset, Seymour M. (1959) "Some Social Requisites of

Democracy: Economic Development and Political Legitimacy," American Political Science Review, 53, 69-105.

Lockhart, James B. (1969) "Encomienda and Hacienda: the Evolution of the Great Estate in the Spanish Indies," Hispanic American Historical Review, 49, 411-429.

Lockhart, James and Stuart B. Schwartz (1983) Early Latin America, Cambridge University Press, New York NY.

Maurer, Noel (2002) The Power and the Profits: The Mexican Financial System, 1876-1932, Stanford; Stanford University Press.

Mazzuca, Sebastián and James A. Robinson (2004) "Political Conflict and Powersharing in the Origins of Modern Colombia," Unpublished, Department of Government, Harvard University.

McIntyre, Andrew (2001a) "Institutions and Investors: The Politics of the Economic Crisis in Southeast Asia," International Organization, 55, 81-122.

McIntyre, Andrew (2001b) "Rethinking the Politics of Agricultural Policy Making: the Importance of Institutions," in Ammar Siamwalla ed. The Evolving Roles of State, Private and Local Actors in Asian Rural Development, Hong Kong; Oxford University Press.

McIntyre, Andrew (2001c) "Investment, Property Rights, and Corruption in Indonesia," in J. Edgar Campos ed. Corruption: The Boom and the Bust of East Asia, Manila; Ateneo University Press.

McNaught, Kenneth W.K. (1988) The Penguin History of Canada, New York; Penguin Books.

Melo, Jorge Orlando (1996) Historia de Colombia: La Dominación Española, Bogotá; Biblioteca Familiar. Montinola, Gabriella, Yingyi Qian, and Barry Weingast (1995) "Federalism Chinese Style: The Political
Basis for Economic Success in Chine," World Politics, 48, 50-81.

Moore, Barrington (1966) Social Origins of Dictatorship and Democracy, Boston; Beacon Press. Morgan, Edmund S. (1975) American Slavery, American Freedom; The Ordeal of Colonial Virginia, New York; W.W. Norton \& Co..

Mörner, Magnus (1973) "The Spanish American Hacienda: A Survey of Recent Research and Debate," Hispanic American Historical Review, 53, 183-216.

North, Douglas C. (1981) Structure and Change in Economic History, W.W. Norton \& Co., New York.

North, Douglass C. and Robert P. Thomas (1973) The Rise of the Western World: A New Economic History, Cambridge University Press, Cambridge UK.

North, Douglass C. and Barry R. Weingast (1989) "Constitutions and Commitment: Evolution of Institutions Governing Public Choice in Seventeenth Century England, Journal of Economic History, 49, 803-832.

O’Brien, Patrick K. (1993) "Political Preconditions for the Industrial Revolution,” in Patrick K. O’Brien and R. Quinault eds. The Industrial Revolution and British Society, New York; Cambridge University Press.

O'Rourke, Kevin J. and Jeffrey G. Williamson (2005) "From Malthus to Ohlin: Trade, Growth and Distribution Since 1500," Journal of Economic Growth, 10, 5-34.

Oi, Jean C. (1992) "Fiscal Reform and the Economic Foundations of Local State Corporatism in China," World Politics, 45, 99-126.

Parry, John H. (1948) The Audiencia of New Galicia in the sixteenth century; a study in Spanish colonial government, New York; Cambridge University Press.

Perry, Elizabeth J. and Christine Wong eds. (1985) The Political Economy of Reform in Post-Mao China, Cambridge; Harvard University Press.

Putterman, Louis (1995) "The Role of Ownership and Property Rights in China's Economic Transition," China Quarterly, 144, 1047-1064.

Qian, Yingyi (2003) "How Reform Worked in China," in Dani Rodrik ed. In Search of Prosperity: Analytic Narratives on Economic Growth, Princeton; Princeton University Press.

Rock, Michael T. (2002) "The Politics of Development Policy and Development Policy Reform in New Order Indonesia," University of Michigan, William Davidson Institute Working Paper \#632. 
Rodrik, Dani (1999) "Democracies Pay Higher Wages," Quarterly Journal of Economics, CXIV, 707-738.

Rueschmeyer, Dietrich, Evelyne Huber Stephens and John D. Stephens (1992) Capitalist Development and Democracy, Chicago; University of Chicago Press.

Samuels, David and Richard Snyder (2001) "Devaluing the Vote in Latin America," Journal of Democracy, 12, 146-159.

Shirk, Susan L. (1993) The Political Logic of Economic Reform in China, Berkeley; University of California Press.

Smith, Peter H. (1978) "The Breakdown of Democracy in Argentina, 1916-1930," in Juan J. Linz and Alfred Stepan eds. The Breakdown of Democratic Regimes: Latin America, Baltimore; Johns Hopkins University Press.

Stasavage, David (2003) Public Debt and the Birth of the Democratic State: France and Great Britain 1688-1789, New York; Cambridge University Press.

Stern, Joseph J. (2003) "The Rise and Fall of the Indonesian Economy," Harvard University, J.F.K. School of Government, CID Working Paper No. 100.

Tarrow, Sidney (1998) Power in Movement: Social Movements and Contentious Politics, Second Edition, New York; Cambridge University Press.
Tawney, R.H. (1941) "The Rise of the Gentry, 15581640," Economic History Review, 11, 1-38.

Thompson, Edward P. (1963) The Making of the English working class, New York; Pantheon Books.

Thompson, Edward P. (1975) Whigs and hunters: the origin of the Black act, New York; Pantheon Books.

Tilly, Charles (1995) Popular Contention in Britain, 1758-1834, Cambridge; Harvard University Press.

Walder, Andrew G. and Jean C. Oi (1999) "Property Rights in the Chinese Economy: Contours of the Process of Change," in Walder, Andrew G. and Jean C. Oi eds. Property Rights and Economic Reform in China, Stanford; Stanford University Press.

Widner, Jennifer A. (1993) "The Origins of Agricultural Policy in the Ivory Coast, 1960-1986," Journal of Development Studies, 29, 25-60.

Weingast, Barry R. (1998) "Political Stability and Civil War: Institutions, Commitment, and American Democracy," in Robert Bates, Avner Greif, Margaret Levi, Jean-Laurent Rosenthal and Barry R. Weingast eds. Analytic Narratives. Princeton; Princeton University Press.

Williamson, Jeffrey G. (1985) Did British Capitalism Breed Inequality? Allen and Unwin, Boston MA.

World Bank (1993) The East Asian Miracle, Washington DC.; The World Bank. 